\title{
Activation of tetrafluoropropenes by rhodium(ı) germyl and silyl complexes $\uparrow$
}

\author{
Maria Talavera, (D) a Robert Müller, (D) b Theresia Ahrens, ${ }^{a}$ Cortney N. von \\ Hahmann, ${ }^{a}$ Beatrice Braun-Cula, (D) a Martin Kaupp (iD *b \\ and Thomas Braun (D) *a
}

Received 3rd May 2019, Accepted 27th June 2019

DOI: $10.1039 / c 9 f d 00059 c$

The reaction of the rhodium(I) complexes $\left[\mathrm{Rh}(\mathrm{E})\left(\mathrm{PEt}_{3}\right)_{3}\right]\left(\mathrm{E}=\mathrm{GePh}_{3}(1), \mathrm{Si}(\mathrm{OEt})_{3}(5)\right)$ with HFO-1234yf (2,3,3,3-tetrafluoropropene) afforded $\left[\mathrm{Rh}(\mathrm{F})\left(\mathrm{PEt}_{3}\right)_{3}\right]$ (2) and the functionalized olefins $Z-\mathrm{CF}_{3} \mathrm{CH}=\mathrm{CH}(\mathrm{E}) \quad\left(\mathrm{E}=\mathrm{GePh}_{3} \text { (4a), Si(OEt) }\right)_{3}$ (7)). Conceivable reaction pathways were assessed using DFT calculations. Reactions of $\left[\mathrm{Rh}(\mathrm{E})\left(\mathrm{PEt}_{3}\right)_{3}\right]$ with HFO-1234ze (E-1,3,3,3-tetrafluoropropene) yielded the rhodium fluorido complex 2 and $\left[\mathrm{Rh}\left\{(E)-\mathrm{CH}=\mathrm{CH}\left(\mathrm{CF}_{3}\right)\right\}\left(\mathrm{PEt}_{3}\right)_{3}\right]$ (9) via two different reaction pathways. Using complexes 1 and 5 as catalysts, functionalized building blocks were obtained.

\section{Introduction}

The chemistry of fluorinated compounds has grown in recent decades due to their broad applications as building blocks in various fields, such as for agrochemicals or pharmaceuticals or in material science. ${ }^{1}$ The fluorinated tetrafluoropropenes HFO1234yf (2,3,3,3-tetrafluoropropene) and HFO-1234ze (E-1,3,3,3-tetrafluoropropene) show good environmental properties which qualify them to be useful as refrigerants, but they might also be interesting substrates for obtaining new building blocks. ${ }^{2}$ Reactivity studies are rather rare, but involve some organometallic transformations such as C-F bond activation reactions. ${ }^{3}$ Thus, Ogoshi and co-workers have described monodefluoroborylation and monodefluorosilylation reactions of both HFO-1234yf and HFO-1234ze using a copper catalyst and Bpin ( pin = pinacolate) derivatives. ${ }^{3 \boldsymbol{b}, \boldsymbol{d}}$ In addition, Crimmin et al. used an aluminum(I) complex for an oxidative addition of the fluoroolefins resulting in a $\mathrm{C}-\mathrm{F}$ bond activation. ${ }^{3 a}$ We recently reported exceptional $\mathrm{C}-\mathrm{H}$ bond activation at HFO-1234yf initiated by the rhodium(I) fluorido

\footnotetext{
${ }^{a}$ Humboldt-Universität zu Berlin, Department of Chemistry, Brook-Taylor-Straße 2, 12489 Berlin, Germany. E-mail: thomas.braun@cms.hu-berlin.de; Tel: +49302093 3913

${ }^{b}$ Institut für Chemie, Theoretische Chemie/Quantenchemie, Technische Universität Berlin, Sekr. C7, Straße des 17. Juni 135, 10623 Berlin, Germany. E-mail: martin.kaupp@tu-berlin.de

$\dagger$ Electronic supplementary information (ESI) available: NMR spectra for all reactions, additional DFT details and $x y z$ coordinates for all calculated compounds. CCDC 1912055. For ESI and crystallographic data in CIF or other electronic format see DOI: 10.1039/c9fd00059c
} 


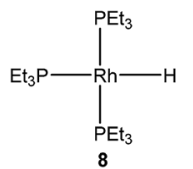

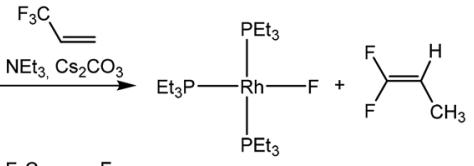

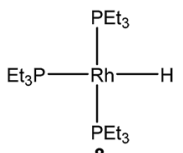

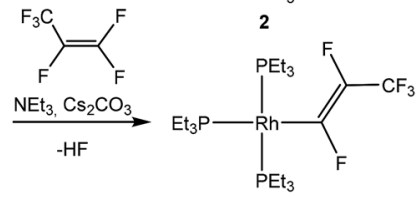

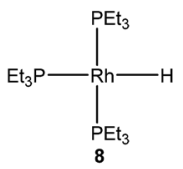

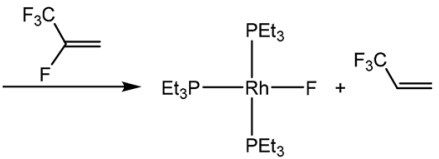

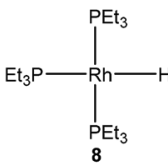<smiles>C=C[C@H](F)[C@@H](C)c1ccccc1</smiles>

Scheme 1 Known reactivity pathways of $\left[\mathrm{Rh}(\mathrm{H})\left(\mathrm{PEt}_{3}\right)_{3}\right](8)$ towards fluoroolefins.

complex 2 in the presence of fluorosilanes to yield $\left[\mathrm{Rh}\left\{(E)-\mathrm{C}\left(\mathrm{CF}_{3}\right)=\mathrm{CHF}\right\}\left(\mathrm{PEt}_{3}\right)_{3}\right](3){ }^{4}$ The conversion also involves a 1,2-fluoride shift (Scheme 1). Catalytic hydrodefluorination reactions on using the rhodium hydrido complex $\left[\mathrm{Rh}(\mathrm{H})\left(\mathrm{PEt}_{3}\right)_{3}\right](8)$ as catalyst were also observed. ${ }^{4}$

$\mathrm{C}-\mathrm{F}$ bond activation reactions of fluoroorganics at transition metal complexes are well-known, ${ }^{5}$ and a useful strategy to achieve this activation consists of the formation of a thermodynamically stable B-F, Si-F, Ge-F, H-F or Al-F bond. ${ }^{5 s, 6}$ Interesting rhodium complexes to activate fluoroolefins are, in addition to $\left[\mathrm{Rh}(\mathrm{H})\left(\mathrm{PEt}_{3}\right)_{3}\right](\mathbf{8}),{ }^{7}$ the rhodium(I) germyl complex $\left[\mathrm{Rh}\left(\mathrm{GePh}_{3}\right)\left(\mathrm{PEt}_{3}\right)_{3}\right](\mathbf{1})^{\mathbf{8}}$ and the rhodium(I) silyl complex $\left[\mathrm{Rh}\left(\mathrm{Si}(\mathrm{OEt})_{3}\right)\left(\mathrm{PEt}_{3}\right)_{3}\right](5) .{ }^{9}$ Reactivity studies revealed that they exhibit different reaction pathways towards fluorinated olefins, such as
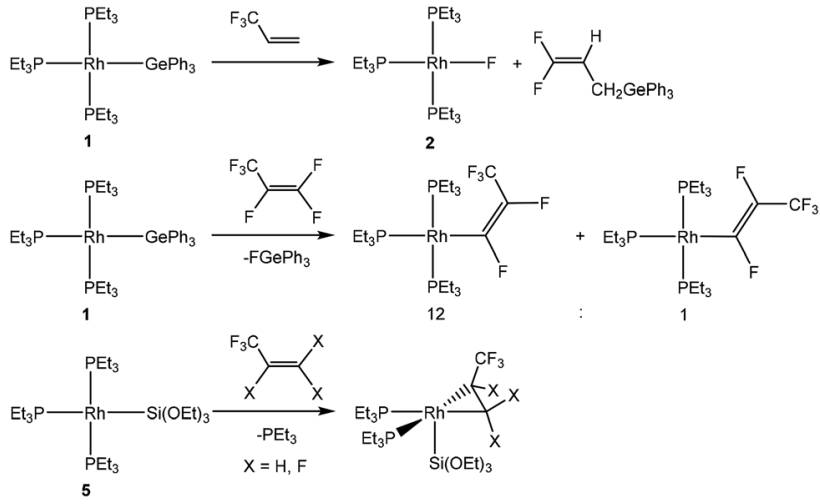

Scheme 2 Known reactivity patterns of $\left[\mathrm{Rh}(\mathrm{E})\left(\mathrm{PEt}_{3}\right)_{3}\right]\left(\mathrm{E}=\mathrm{GePh}_{3}(1), \mathrm{Si}(\mathrm{OEt})_{3}(5)\right)$ towards fluoroolefins. 
olefin coordination to complex 5. Alternatively, C-F bond activation steps lead either to the formation of a rhodium-carbon bond to form a fluorinated ligand or to the formation of a rhodium-fluorine bond and a derived fluorinated olefin. Examples are shown in Schemes 1 and 2 of the reactivity of complexes 1, 5 or 8 with hexafluoropropene ${ }^{8,10}$ and 3,3,3-trifluoropropene. ${ }^{7 d}$

Herein, we report the behavior of $\left[\mathrm{Rh}\left(\mathrm{GePh}_{3}\right)\left(\mathrm{PEt}_{3}\right)_{3}\right]$ (1) and $\left[\mathrm{Rh}\left(\mathrm{Si}(\mathrm{OEt})_{3}\right)\left(\mathrm{PEt}_{3}\right)_{3}\right](5)$ towards the two isomers HFO-1234yf and HFO-1234ze as well as that of $\left[\mathrm{Rh}(\mathrm{H})\left(\mathrm{PEt}_{3}\right)_{3}\right](8)$ towards HFO-1234ze. Conceivable activation reactions include $\mathrm{C}\left(\mathrm{sp}^{3}\right)-\mathrm{F}$ or $\mathrm{C}\left(\mathrm{sp}^{2}\right)-\mathrm{F}$ bond cleavage or $\mathrm{C}-\mathrm{H}$ bond activation, opening up several opportunities for derivatization pathways. The studies describe $\mathrm{C}-\mathrm{H}$ bond activation, $\mathrm{C}-\mathrm{F}$ bond activation and olefin coordination as well as catalytic $\mathrm{C}-\mathrm{F}$ bond activation, germylation and silylation reactions.

\section{Results and discussion}

\section{Reactions towards HFO-1234yf (2,3,3,3-tetrafluoropropene)}

Treatment of the rhodium(I) germyl complex $\left[\mathrm{Rh}\left(\mathrm{GePh}_{3}\right)\left(\mathrm{PEt}_{3}\right)_{3}\right]$ (1) with HFO$1234 y f$ in benzene- $\mathrm{d}_{6}$ afforded as the main product the fluorido complex $\left[\mathrm{Rh}(\mathrm{F})\left(\mathrm{PEt}_{3}\right)_{3}\right](2)$ and $12 \%$ of the alkenyl complex $\left[\mathrm{Rh}\left\{(E)-\mathrm{C}\left(\mathrm{CF}_{3}\right)=\mathrm{CHF}\right\}\left(\mathrm{PEt}_{3}\right)_{3}\right](3)$, both of which have been previously described. ${ }^{4,7 c, 11}$ Additionally, the germylated trifluoropropene $\mathrm{Z}-\mathrm{CF}_{3} \mathrm{CH}=\mathrm{CH}\left(\mathrm{GePh}_{3}\right)(\mathbf{4 a})$ as well as traces of an unknown rhodium complex (5\%) were obtained (Scheme 3$)$. Note that complex 3 might be formed from 2 by $\mathrm{C}-\mathrm{H}$ activation which is mediated by a germane, as previously observed for boranes and silanes. ${ }^{4}$ The latter act as Lewis-acids and after fluoride abstraction, the $\mathrm{C}-\mathrm{H}$ activation step at the coordinated olefin is induced by the fluoroborate or fluorosilicate, respectively, to yield 3 and HF.

The ${ }^{19} \mathrm{~F}$ NMR spectrum of 4 a shows a doublet at $\delta-62.2 \mathrm{ppm}\left({ }^{3} J(\mathrm{~F}, \mathrm{H})=7 \mathrm{~Hz}\right)$ for the $\mathrm{CF}_{3}$ group due to a coupling to the proton in the geminal position. The signals of the olefinic protons in the ${ }^{1} \mathrm{H}$ NMR spectrum appear at $\delta 6.45$ and $6.28 \mathrm{ppm}$ as part of an $\mathrm{ABX}_{3}$ system (see ESI $\dagger$ for simulation) with a proton-proton cis coupling of $14.3 \mathrm{~Hz}$ and proton-fluorine couplings of 0.34 and $7.87 \mathrm{~Hz}$ for the trans and the geminal protons with respect to the $\mathrm{CF}_{3}$ group. A similar cis $\mathrm{H}, \mathrm{H}$ coupling is reported for the vinylic protons in $Z-\mathrm{CF}_{3} \mathrm{CH}=\mathrm{CH}\left(\mathrm{SiMe}_{3}\right)$ with a trans $\mathrm{H}, \mathrm{F}$ coupling constant of $c a .0 .5 \mathrm{~Hz},{ }^{12}$ which supports the assignment of a cis configuration in 4a. Suitable crystals for the X-ray crystallography analysis have also been obtained and the structure, bond lengths and angles are shown in Fig. 1. The unit cell contains two independent molecules in the asymmetric unit, which exhibit comparable bond lengths and angles. Therefore, only one molecule will be discussed.

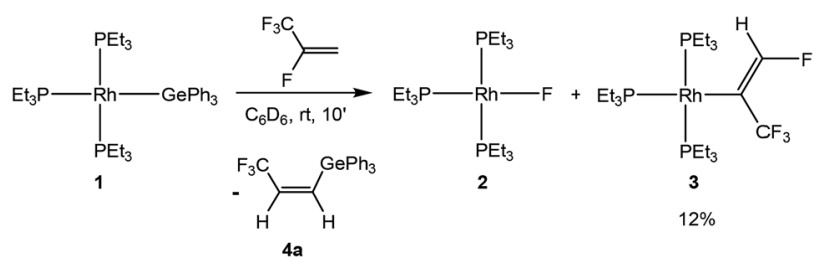

Scheme 3 Reaction of the rhodium(ı) germyl complex 1 with HFO-1234yf. 


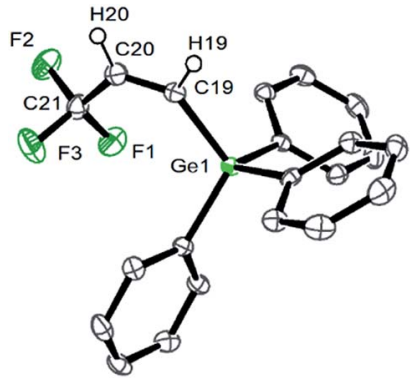

Fig. 1 ORTEP diagram of one of the independent molecules in the unit cell of $\mathrm{Z}-\mathrm{CF}_{3} \mathrm{CH}=\mathrm{CH}\left(\mathrm{GePh}_{3}\right)$ (4a) drawn at the $50 \%$ probability level. Hydrogen atoms of the phenyl rings are not shown for clarity. Selected bond lengths (Å) and angles $\left({ }^{\circ}\right)$ : $\mathrm{Ge}(1)-\mathrm{C}(19)$, 1.965(2); $C(19)-C(20), 1.325(3) ; C(20)-C(21), 1.476(3) ; F(1)-C(21), 1.335(3) ; F(2)-C(21)$, 1.352(3); $F(3)-C(21), 1.346(3) ; C(20)-C(19)-G e(1), 133.07(19) ; C(19)-C(20)-C(21), 125.8(2)$.

The molecular structure of $\mathbf{4 a}$ confirms the cis arrangement at the olefin moiety, and the $\mathrm{C}-\mathrm{F}$ bond lengths of the trifluoropropene unit have typical values. ${ }^{13}$ The $\mathrm{C}-\mathrm{Ge}$ bond distance $(1.965(2) \AA)$ is similar to that of $\mathrm{C}-\mathrm{Ge}$ bonds in other germylated fluoroolefins such as $\mathrm{CHF}=\mathrm{CF}\left(\mathrm{GePh}_{3}\right)(1.958(9) \AA){ }^{\mathbf{1 4}}$ $\mathrm{CF}_{2}=\mathrm{CCl}\left(\mathrm{GePh}_{3}\right)(1.954(5) \AA)^{15}$ and $\mathrm{CF}_{3} \mathrm{CF}=\mathrm{CF}\left(\mathrm{GePh}_{3}\right)(1.993(5) \AA) .{ }^{16}$ The Ge $\cdots$ F1 distance of $3.105 \AA$ is $c a .0 .4 \AA$ less than the sum of the van-der-Waals radii. ${ }^{17}$ A comparable separation has been discussed for $\mathrm{CF}_{3} \mathrm{CF}=\mathrm{CF}\left(\mathrm{GePh}_{3}\right)$ as a short intramolecular contact. ${ }^{16}$

To assess the behavior of HFO-1234yf further, the reaction with $\left[\mathrm{Rh}(\mathrm{SiOEt})_{3}\left(\mathrm{PEt}_{3}\right)_{3}\right](5)$ was studied. Treatment of complex 5 with HFO-1234yf in toluene- $\mathrm{d}_{8}$ yielded, in 10 minutes, the rhodium fluorido complex 2 and the cationic species $\left[\mathrm{Rh}\left(\mathrm{PEt}_{3}\right)_{4}\right]^{+}(6)^{18}$ in a $90: 10$ ratio as well as 3,3,3-trifluoropropene and $Z-\mathrm{CF}_{3} \mathrm{CH}=\mathrm{CH}\left(\mathrm{Si}(\mathrm{OEt})_{3}\right)(7)$ (Scheme 4). Compound 7 exhibits a doublet for the $\mathrm{CF}_{3}$ group at $\delta-63.9 \mathrm{ppm}$ in the ${ }^{19} \mathrm{~F}$ NMR spectrum with a coupling constant to the proton in the geminal position of $8 \mathrm{~Hz}$. In the ${ }^{1} \mathrm{H}$ NMR spectrum, an $\mathrm{ABX}_{3}$ system (see ESI $\dagger$ for simulation) for the olefinic protons

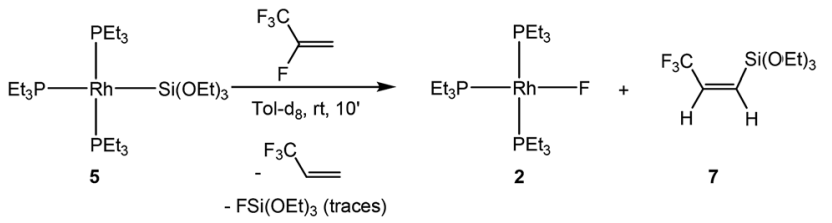

$$
\stackrel{\mathrm{F}}{\mathrm{F}_{3} \mathrm{C}, 18 \mathrm{~h}}
$$

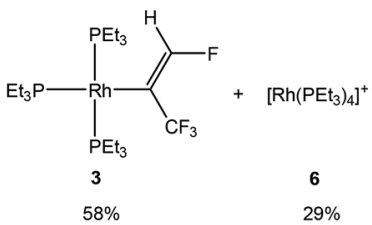

Scheme 4 Reaction pathways of the rhodium(I) silyl complex 5 with HFO-1234yf. 
appears at $\delta 6.07$ and $5.96 \mathrm{ppm}$ as an apparent doublet of quartets and a doublet, respectively. The proton-proton coupling constant of $15.54 \mathrm{~Hz}$ as well as the H,F coupling constant of less than $0.5 \mathrm{~Hz}$ to the non-vicinal proton suggests, as in the case of compound 4a, a cis configuration of the hydrogen atoms. Finally, the ${ }^{1} \mathrm{H}$, ${ }^{29} \mathrm{Si}$ HMBC NMR spectrum confirms the presence of the silylated group with a correlation peak between its geminal proton and the silicon nucleus at $-69.8 \mathrm{ppm}$ in the silicon domain.

The mixture of 2 and the olefin 7 is not stable and it reacts further in the presence of HFO-1234yf to yield complex $\left[\mathrm{Rh}\left\{(E)-\mathrm{C}\left(\mathrm{CF}_{3}\right)=\mathrm{CHF}\right\}\left(\mathrm{PEt}_{3}\right)_{3}\right](3)$ and approximately $13 \%$ of an unknown complex after 18 hours. The silylated olefin 7 presumably acts as a fluoride acceptor to activate the rhodium fluorido complex 2 , forming complex 3 by the $\mathrm{C}-\mathrm{H}$ activation of HFO-1234yf and a subsequent 1,2fluorine shift. Such a reaction pattern was previously described for $\mathrm{FSiPh}_{3} .{ }^{4}$ Thus, mechanistically, as already indicated above, fluorosilicate generation from $\left[\mathrm{Rh}(\mathrm{F})\left(\mathrm{PEt}_{3}\right)_{3}\right](2)$ and silane followed by a $\mathrm{C}-\mathrm{H}$ bond activation and a concomitant $\mathrm{HF}$ formation was postulated based on computational studies. Independent reactions suggested that the intermediate $\left[\mathrm{Rh}\left\{(E)-\mathrm{C}(\mathrm{H})=\mathrm{CF}\left(\mathrm{CF}_{3}\right)\right\}\left(\mathrm{PEt}_{3}\right)_{3}\right]$ then rearranges by a 1,2-fluorine shift to furnish 3 . The latter rearrangement is distinctive and was also observed in the reactions of HFO-1234yf with $\left[\mathrm{Rh}\left(\mathrm{CH}_{3}\right)\left(\mathrm{PEt}_{3}\right)_{3}\right]$ and $\left[\mathrm{Rh}\left(\mathrm{C}_{6} \mathrm{D}_{7}\right)\left(\mathrm{PEt}_{3}\right)_{3}\right] .^{4}$

A reasonable mechanism for the formation of the fluorido complex $\left[\mathrm{Rh}(\mathrm{F})\left(\mathrm{PEt}_{3}\right)_{3}\right](2)$ and the olefins $Z-\mathrm{CF}_{3} \mathrm{CH}=\mathrm{CH}(\mathrm{E})\left(\mathrm{E}=\mathrm{GePh}_{3}(\mathbf{4 a}), \mathrm{Si}(\mathrm{OEt})_{3}(7)\right)$ from the germyl complex $\left[\mathrm{Rh}\left(\mathrm{GePh}_{3}\right)\left(\mathrm{PEt}_{3}\right)_{3}\right]$ (1) or the silyl complex $\left[\mathrm{Rh}\left(\mathrm{Si}(\mathrm{OEt})_{3}\right)\left(\mathrm{PEt}_{3}\right)_{3}\right](5)$ would imply a two-step process of $\mathrm{C}-\mathrm{H}$ and $\mathrm{C}-\mathrm{F}$ bond activation reactions. Thus, $\mathrm{C}-\mathrm{H}$ bond activation may occur via an initial coordination of HFO-1234yf at the rhodium(I) complex in the first step to form the complex A (Fig. 2 and 3, red line), followed by its insertion into the Rh-Ge or Rh-Si bond. An intramolecular $\mathrm{C}-\mathrm{H}$ oxidative addition would subsequently yield a rhodacycle derivative $\mathbf{C}$, which undergoes insertion into the rhodium-hydrogen bond (Fig. 2 and 3, blue line). Finally, C-F bond activation via a $\beta$-fluoride elimination would afford the rhodium fluorido complex 2 and the corresponding olefin $Z$ -

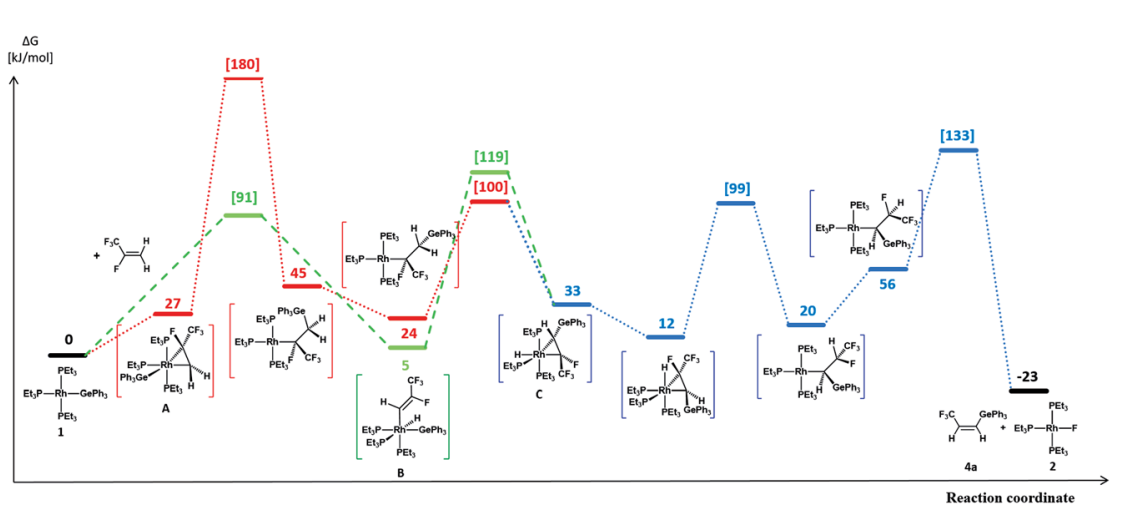

Fig. 2 Calculated profiles for the activation of HFO-1234yf with complex 1. All calculated reaction and activation free energies (298.15 K, $0.1 \mathrm{MPa} ; \Delta G^{\neq}$in square brackets) are given relative to the separate reactants 1 and HFO-1234yf (RI-BP86-D3(BJ)/def2-SVP/ $\cos M O($ toluene)). 


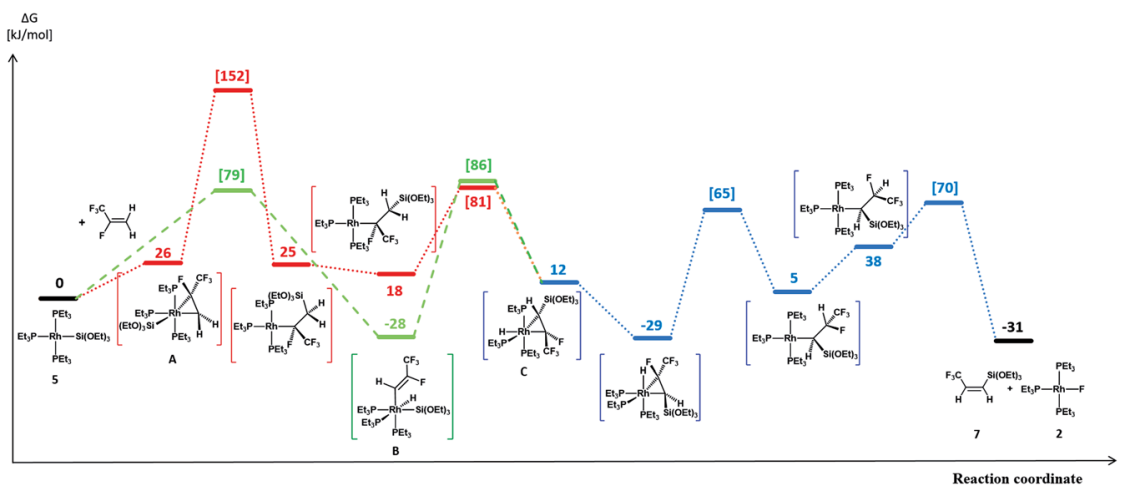

Fig. 3 Calculated profiles for the activation of HFO-1234yf with complex 5. All calculated reaction and activation free energies (298.15 K, $0.1 \mathrm{MPa} ; \Delta G^{\neq}$in square brackets) are given relative to the separate reactants 5 and HFO-1234yf (RI-BP86-D3(BJ)/def2-SVP/ cOSMO(toluene)).

$\mathrm{CH}\left(\mathrm{CF}_{3}\right)=\mathrm{CHE}\left(\mathrm{E}=\mathrm{GePh}_{3}(\mathbf{4 a}), \mathrm{Si}(\mathrm{OEt})_{3}(7)\right)$. Alternatively, intermolecular $\mathrm{C}-\mathrm{H}$ activation in the initial reaction step would furnish the rhodium-alkenyl complex B (Fig. 2 and 3, green line). This complex could subsequently rearrange to $\mathbf{C}$ by a reductive elimination, again followed by an insertion into the $\mathrm{Rh}-\mathrm{H}$ bond and subsequent $\beta$-fluoride elimination. Stereoselective insertion and elimination steps of the $\beta$-hydride and $\beta$-fluoride would determine the final cis configuration of the functionalized olefin. Note that in comparable conversions such reaction steps of fluorinated olefins showed a high stereoselectivity. ${ }^{19}$ In order to assess the feasibility of the proposed mechanism, DFT calculations were carried out for all reaction sequences depicted in Fig. 2 and 3. The overall reaction of complexes $\left[\mathrm{Rh}(\mathrm{E})\left(\mathrm{PEt}_{3}\right)_{3}\right]\left(\mathrm{E}=\mathrm{GePh}_{3}(\mathbf{1}), \mathrm{Si}(\mathrm{OEt})_{3}(5)\right)$ with HFO-1234yf to afford 2 and $4 \mathrm{a} / 7$ is calculated to proceed exergonically by $-23 \mathrm{~kJ} \mathrm{~mol}^{-1}$ and by $-31 \mathrm{~kJ} \mathrm{~mol}^{-1}$ for 1 and $\mathbf{5}$, respectively.

Formation of the prereactive complex A with subsequent insertion of HFO$1234 \mathrm{yf}$ into the Rh-E bond exhibits rather high barriers for both systems $\left(\Delta G^{\neq}=+180 \mathrm{~kJ} \mathrm{~mol}^{-1}(\mathbf{1}) /+152 \mathrm{~kJ} \mathrm{~mol}^{-1}(\mathbf{5})\right)$, which clearly renders this partial reaction the rate-determining step of this particular branch $(\mathbf{1} / \mathbf{5} \rightarrow \mathbf{A} \rightarrow \mathbf{C} \rightarrow \mathbf{2}+$ 4a/7, Fig. 2 and 3 red $\rightarrow$ blue lines). In contrast, an initial intermolecular $\mathrm{C}-\mathrm{H}$ activation of HFO-1234yf at 1/5 to form intermediate $\mathbf{B}$ shows a much lower barrier $\left(\Delta G^{\neq}=+91 \mathrm{~kJ} \mathrm{~mol}^{-1}(\mathbf{1}) /+79 \mathrm{~kJ} \mathrm{~mol}^{-1}(5)\right)$. In addition, the subsequent reductive elimination by migration of the functional group $\mathrm{E}(\mathbf{1} / \mathbf{5} \rightarrow \mathbf{B} \rightarrow \mathbf{C} \rightarrow \mathbf{2}+$ 4a/7, Fig. 2 and 3 green $\rightarrow$ blue lines) also exhibits greatly reduced barriers $\left(\Delta G^{\neq}=+119 \mathrm{~kJ} \mathrm{~mol}^{-1}(\mathbf{1}) /+86 \mathrm{~kJ} \mathrm{~mol}^{-1}(5)\right)$ compared to the migration of $\mathrm{E}$ to the $\mathrm{RhCH}_{2}$ moiety of $\mathbf{A}$. Note that $\beta$-fluoride elimination is now rate-determining for the formation of $\mathbf{4 a}$ in this reaction sequence. It can be concluded that the reaction of $\mathbf{1} / \mathbf{5}$ with HFO-1234yf most likely proceeds via a kinetically favored $\mathrm{C}-\mathrm{H}$ oxidative addition in the first step, which in turn provides the basis for a kinetically feasible functionalization of the alkene by a reductive elimination step. For complex 5, the calculations further indicate that the proposed insertion and $\beta$ fluoride elimination steps, which follow the formation of $\mathbf{C}$, exhibit comparable reaction barriers, supporting the plausibility of the proposed mechanism for 
a reaction at room temperature. However, despite expected effects due to the different steric and electronic natures of the $\mathrm{Si}(\mathrm{OEt})_{3}$ and $\mathrm{GePh}_{3}$ functional groups, the calculated barrier for $\beta$-fluoride elimination of the latter system appears too high for a reaction at room temperature. This might possibly indicate the existence of a lower-energy pathway for the final formation of $\mathbf{4 a}$, which has not been considered here.

\section{Reactions towards HFO-1234ze (E-1,3,3,3-tetrafluoropropene)}

An interesting isomer of HFO-1234yf is the fluoroolefin HFO-1234ze $(E-1,3,3,3-$ tetrafluoropropene), which exhibits some differences in reactivity towards the rhodium(I) hydrido complex $\left[\mathrm{Rh}(\mathrm{H})\left(\mathrm{PEt}_{3}\right)_{3}\right](\mathbf{8})$ when compared to the reaction of 8 with HFO-1234yf. In the latter case, complex 8 selectively activates the $\mathrm{C}\left(\mathrm{sp}^{2}\right)-\mathrm{F}$ bond of the olefin to form the rhodium fluorido complex $\left[\mathrm{Rh}(\mathrm{F})\left(\mathrm{PEt}_{3}\right)_{3}\right](2)$ and 3,3,3-trifluoropropene (see Scheme 1). ${ }^{4}$ When HFO-1234ze is used, treatment of complex 8 with the fluorinated alkene gave within minutes at room temperature the rhodium fluorido complex 2 as well as 3,3,3-trifluoropropene, but also [ $\operatorname{Rh}\{(E)$ $\left.\left.\mathrm{CH}=\mathrm{CH}\left(\mathrm{CF}_{3}\right)\right\}\left(\mathrm{PEt}_{3}\right)_{3}\right](\mathbf{9})^{4}$ and $\mathrm{HF}$ through $\mathrm{C}-\mathrm{F}$ bond activation (Scheme 5).

As has been described for the reaction of 8 with the isomer HFO-1234yf, ${ }^{4}$ low temperature NMR studies revealed that the fluoroolefin initially coordinates to the rhodium hydrido complex to give $f a c$ - $\left[\mathrm{RhH}\left(\eta^{2}-\mathrm{CHF}=\mathrm{CHCF}_{3}\right)\left(\mathrm{PEt}_{3}\right)_{3}\right](\mathbf{1 0})$, which undergoes insertion and $\beta$-fluorine elimination to yield complex 2 . Alternatively, C-F bond activation occurs to form 9, and $\mathrm{HF}$ is released (Scheme 5). The obtaining of the rhodium alkenyl complex 9 resembles the $\mathrm{C}-\mathrm{F}$ bond activation at 8 observed with hexafluoropropene (see introduction, Scheme 1) and some conversions with fluoroaromatic compounds, although $\mathrm{C}-\mathrm{H}$ bond activation is usually preferred. ${ }^{7 a, 20}$

Complex 10 was only observable in NMR measurements at low temperatures. The ${ }^{31} \mathrm{P}\left\{{ }^{1} \mathrm{H}\right\}$ NMR spectrum at $243 \mathrm{~K}$ shows three inequivalent resonances at $\delta$ 19.3, 10.2 and $6.1 \mathrm{ppm}$, with similar rhodium-phosphorus and phosphorusphosphorus coupling constants as found for the previously described analogs $\left[\mathrm{RhH}\left(\eta^{2}\right.\right.$-olefin $\left.)\left(\mathrm{PEt}_{3}\right)_{3}\right]$ (olefin = 3,3,3-trifluoropropene, HFO-1234yf). ${ }^{4,7 d}$ The signal at lower field, which corresponds to the phosphine in the trans position to the $\mathrm{CF}_{3}$ moiety, shows coupling to both fluorine groups of around $16 \mathrm{~Hz}$. The signal for a phosphine at $\delta 10.2 \mathrm{ppm}$ exhibits a larger P,F coupling of $49.3 \mathrm{~Hz}$ to

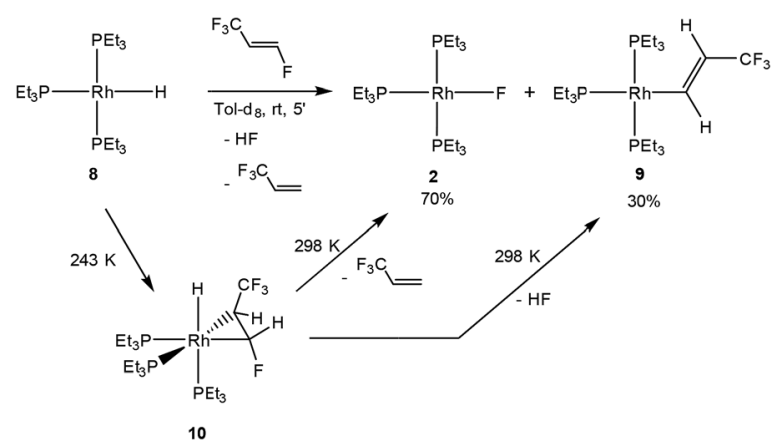

Scheme 5 Reactivity of rhodium hydrido complex 8 towards HFO-1234ze. 
the $\mathrm{CFH}$ group due to its trans arrangement. The resonance at $\delta 6.1 \mathrm{ppm}$ also exhibits a $\mathrm{P}, \mathrm{F}$ coupling to the $\mathrm{CFH}$ group of around $39 \mathrm{~Hz}$. These couplings are confirmed by the ${ }^{19} \mathrm{~F}\left\{{ }^{1} \mathrm{H}\right\}$ NMR spectrum. Thus, the resonance of the $\mathrm{CF}_{3}$ group appears at $\delta-53.6 \mathrm{ppm}$ as a doublet of triplets due to its coupling to the phosphorus atom in the trans position and the phosphorus atom trans to the hydrido ligand as well as the other fluorine atom $\left({ }^{4} \mathrm{~J}=5 \mathrm{~Hz}\right)$. Furthermore, the $\mathrm{CFH}$ group displays a resonance at $\delta-174.4 \mathrm{ppm}$ which is shifted to higher field when compared to signals for fluorinated olefins bearing the trifluoromethyl moiety, ${ }^{7 a, c, 21}$ probably due to the single $\mathrm{C}-\mathrm{C}$ bond character of the coordinated olefin. In the ${ }^{1} \mathrm{H}$ NMR spectrum of 10, the rhodium bound hydrido resonance can be detected at $\delta-14.54 \mathrm{ppm}$ as a doublet of triplets of doublets $(J=156.0,18.9$ and $10.9 \mathrm{~Hz}$ ) due to the couplings to the rhodium and phosphorus atoms, where the coupling to the phosphine in the trans position displays the highest value and that to the rhodium nucleus the lowest. The olefinic protons appear at $\delta 2.88$ and $6.40 \mathrm{ppm}$ as a multiplet and a broad doublet of doublets of doublets, respectively. The latter, corresponding to the CHF moiety, shows a coupling to the fluorine in the geminal position of $69.5 \mathrm{~Hz}$. However, the proton-proton coupling constant of $4.9 \mathrm{~Hz}$ is rather small due to the orientation of the protons. This structural assignment is confirmed by DFT structure optimization of complex 10. That is, the isomer with lower energy (favored by $16.7 \mathrm{~kJ} \mathrm{~mol}^{-1}$ ) has the $\mathrm{CF}_{3}$ group in the cis position to the hydrido ligand, while the fluorine atom of the CHF moiety remains in a trans arrangement. In addition, the $\mathrm{C}-\mathrm{C}$ bond distance of the olefin is $1.448 \AA$, consistent with a metallacyclopropane moiety, suggesting the loss of the double bond character.

The rhodium silyl complex 5 was also treated with HFO-1234ze and after $10 \mathrm{~min}$ the formation of the complex $\left[\mathrm{Rh}\left\{\mathrm{Si}(\mathrm{OEt})_{3}\right\}\left(\eta^{2}-\mathrm{CF}_{3} \mathrm{CH}=\mathrm{CFH}\right)\left(\mathrm{PEt}_{3}\right)_{2}\right](\mathbf{1 1})$ together with $\left[\mathrm{Rh}(\mathrm{F})\left(\mathrm{PEt}_{3}\right)_{3}\right](2)$ in a $89: 9$ ratio, respectively, was observed. Additionally, free phosphine, small amounts of 3,3,3-trifluoropropene and $\mathrm{FSi}(\mathrm{OEt})_{3}$ were present in the reaction mixture (Scheme 6). Note that 3,3,3-trifluoropropene and hexafluoropropene also react with the rhodium silyl complex 5 by coordination and

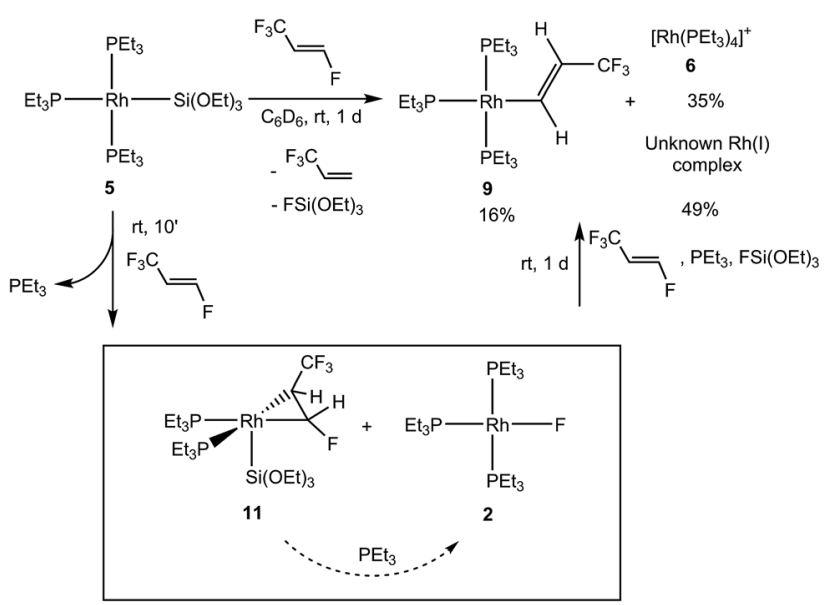

Scheme 6 Reactivity of the rhodium(I) silyl complex 5 towards HFO-1234ze. 
phosphine release (see Scheme 1). ${ }^{7 d, 10}$ After $2 \mathrm{~h}$, the conversion of complex 11 into the rhodium fluorido complex 2 and 3,3,3-trifluoropropene was detected (with a ratio of $2: 11$ of $24: 74$ ). After $1 \mathrm{~d}$, full conversion was observed to obtain an overall mixture of $\left[\mathrm{Rh}\left\{(E)-\mathrm{CH}=\mathrm{CH}\left(\mathrm{CF}_{3}\right)\right\}\left(\mathrm{PEt}_{3}\right)_{3}\right]$ (9), the cationic complex $\left[\mathrm{Rh}\left(\mathrm{PEt}_{3}\right)_{4}\right]^{+}$(6) and an unknown rhodium(I) complex. The formation of fluorosilicates was also observed. While the formation of the rhodium fluorido complex $\mathbf{2}$ and the rhodium alkenyl complex $\mathbf{9}$ involves a C-F bond activation step comparable to the one found for the hydrido complex 8 (see above), formation of the cationic complex can be explained by the reactivity of $\left[\mathrm{Rh}(\mathrm{F})\left(\mathrm{PEt}_{3}\right)_{3}\right](2)$ and $\mathrm{FSi}(\mathrm{OEt})_{3}$ where the fluorosilane acts as a fluorine acceptor, creating the vacant site that the phosphine occupies. ${ }^{4}$

The ${ }^{31} \mathrm{P}\left\{{ }^{1} \mathrm{H}\right\}$ NMR spectrum of complex 11 shows two resonances with an integral ratio of 1:1 for the two inequivalent phosphine ligands. At room temperature, those resonances can be distinguished as doublets of multiplets with rhodium-phosphorus coupling constants of 127.7 and $133.6 \mathrm{~Hz}$, which are closer to the usual values for rhodium(I) complexes. ${ }^{\mathbf{8 , 9 2 2}}$ When the NMR spectra are recorded at $233 \mathrm{~K}$ the coupling with other nuclei can be analyzed. Thus, a signal at $\delta 19.1 \mathrm{ppm}$ appears as a doublet of doublets of doublets due to the coupling to rhodium, phosphorus $\left({ }^{2} J=22.7 \mathrm{~Hz}\right)$ and the olefinic fluorine atom with a coupling constant of $36.3 \mathrm{~Hz}$, suggesting a trans arrangement of the phosphine ligand to the CHF group. The second resonance appears at $\delta 21.1 \mathrm{ppm}$ as a doublet of doublets of quartets of doublets. In this multiplicity, the phosphorus atom not only couples to the olefinic fluorine with a coupling constant of $15.8 \mathrm{~Hz}$, but also shows a quartet due to the coupling to the $\mathrm{CF}_{3}$ group $\left({ }^{4} J=18.4\right.$ $\mathrm{Hz}$ ), which indicates that the $\mathrm{CHCF}_{3}$ is in the trans position. The ${ }^{19} \mathrm{~F}$ NMR spectrum depicts a doublet of doublets of pseudo triplets at $\delta-51.3 \mathrm{ppm}$, which can be assigned to the $\mathrm{CF}_{3}$ group. Apart from the already mentioned coupling to its phosphorus atom in the trans position, it shows coupling to both olefinic protons of $12 \mathrm{~Hz}$ and $3 \mathrm{~Hz}$ and the olefinic fluorine atom of also $3 \mathrm{~Hz}$. The latter leads to a doublet of doublets of triplets of multiplets at high field. The coupling constants to the olefinic protons of 63 and $17 \mathrm{~Hz}$ suggest that the trans configuration of the fluorinated moieties of the olefin is maintained. ${ }^{21}$ The ${ }^{1} \mathrm{H}$ NMR spectrum shows chemical shifts for the olefinic protons at $\delta 3.70$ and $6.67 \mathrm{ppm}$, consistent with the presence of a certain double bond character of the carbon-carbon bond. These protons exhibit a mutual coupling of $6.3 \mathrm{~Hz}$. Finally, the ${ }^{1} \mathrm{H},{ }^{29} \mathrm{Si} \mathrm{HMBC}$ NMR spectrum confirms the coordination of the silyl ligand with a correlation peak at $\delta-54.2 \mathrm{ppm}$ in the Si domain with a Si-Rh coupling constant of around $140 \mathrm{~Hz}$. The chemical shift is similar to the values of previously described rhodium silyl complexes bearing a coordinated fluoroolefin. ${ }^{7 d, 10}$

Finally, treatment of $\left[\mathrm{Rh}\left(\mathrm{GePh}_{3}\right)\left(\mathrm{PEt}_{3}\right)_{3}\right](\mathbf{1})$ with HFO-1234ze yielded, after 16 hours, the rhodium fluorido complex 2, the $\mathrm{C}-\mathrm{F}$ bond activation product $\left[\mathrm{Rh}\left\{(E)-\mathrm{CH}=\mathrm{CH}\left(\mathrm{CF}_{3}\right)\right\}\left(\mathrm{PEt}_{3}\right)_{3}\right](9)$ and an unknown rhodium complex (15\%) as well as 3,3,3-trifluoropropene. The reactivity pattern again resembles the ones found for the activation reactions at $\mathbf{5}$ and $\mathbf{8}$ (Scheme 7). The presence of the $\mathrm{C}-\mathrm{F}$ bond activation product, $\mathrm{CF}_{2}=\mathrm{CHCH}_{2} \mathrm{GePh}_{3}$, in the reaction mixtures suggests a competition between the C-F bond activation of HFO-1234ze and 3,3,3-trifluoropropene (see introduction, Schemes 1 and 2). Note that similar allylic C-F activations have been previously described. ${ }^{3 c, 5 e, i, 7 d}$ While the reaction mechanism is presumably the same, an initial coordination of the olefin was not 


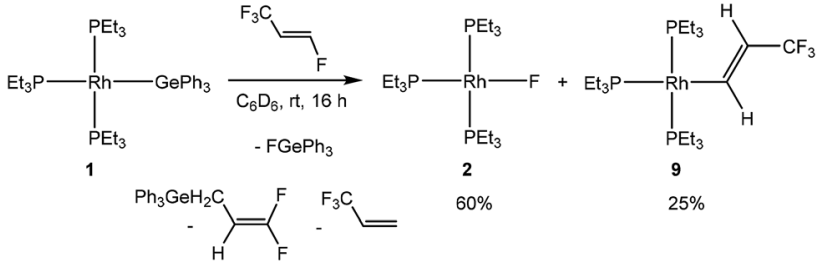

Scheme 7 Reactivity of complex 1 towards HFO-1234ze.

observed using low-temperature NMR spectroscopy as with the hydrido complex 8 and the silyl complex 5. This is consistent with the reactivity of the germyl complex 1 with other fluorinated olefins, where no precoordination was observed in contrast to complexes 5 and $\mathbf{8 .}^{\mathbf{4 , 7 d , 8 , 1 0}}$

\section{Catalytic studies}

Based on the stoichiometric conversions, catalytic reactions with tertiary germanes were also investigated. With the rhodium germyl complex $\left[\mathrm{Rh}\left(\mathrm{GePh}_{3}\right)\left(\mathrm{PEt}_{3}\right)_{3}\right](\mathbf{1})(10 \mathrm{~mol} \%)$ as a catalytic precursor, HFO-1234yf reacts in the presence of $\mathrm{HGeR}_{3}\left(\mathrm{R}=\mathrm{Ph}(\mathbf{a})\right.$, Et (b), $\left.{ }^{n} \mathrm{Bu}(\mathbf{c})\right)$ to yield a mixture of the olefins $Z-\mathrm{CF}_{3} \mathrm{CH}=\mathrm{CH}\left(\mathrm{GeR}_{3}\right)$ (4) and 3,3,3-trifluoropropene as the main products (Scheme 8). After 1 day at room temperature the germanes were fully converted. Small amounts of $\mathrm{CF}_{3} \mathrm{CH}_{3} \mathrm{CH}_{3}, E-\mathrm{CF}_{3} \mathrm{CH}=\mathrm{CH}\left(\mathrm{GeR}_{3}\right)$ (12) (see below) and $\mathrm{CF}_{3} \mathrm{CH}_{3} \mathrm{CH}_{2} \mathrm{GeR}_{3},{ }^{\text {d d }}$ which is the hydrogermylation product of 3,3,3-trifluoropropene, ${ }^{7 d}$ were also generated. The hydrogermylation product of HFO$1234 y$ f was not observed, which is in contrast to the catalytic conversions of 3,3,3-trifluoropropene with tertiary germanes using $\mathbf{1}$ as catalyst. ${ }^{7 d}$

Mechanistically, the formation of $Z-\mathrm{CF}_{3} \mathrm{CH}=\mathrm{CH}\left(\mathrm{GeR}_{3}\right)(4)$ in catalytic amounts is consistent with the stoichiometric reaction of $\left[\mathrm{Rh}\left(\mathrm{GePh}_{3}\right)\left(\mathrm{PEt}_{3}\right)_{3}\right](\mathbf{1})$ with HFO$1234 y f$ as an initial reaction (see above). For $\mathrm{HGePh}_{3}$ possible reaction steps are depicted in Scheme 9. A subsequent reaction of the initial C-F bond activation product $\left[\mathrm{Rh}(\mathrm{F})\left(\mathrm{PEt}_{3}\right)_{3}\right]$ (2) with germane affords the known dihydrido complex $\left[\mathrm{Rh}(\mathrm{H})_{2}\left(\mathrm{GePh}_{3}\right)\left(\mathrm{PEt}_{3}\right)_{3}\right](\mathbf{1 3})^{\mathbf{8}}$ and a small amount of rhodium(I) germyl complex $\mathbf{1}$, as well as fluorogermane. The two germyl complexes are in equilibrium with each other. The generation of 3,3,3-trifluoropropene can be explained by a conversion of complex 13 and HFO-1234yf to form the fluorido complex 2 and 3,3,3-trifluoropropene (Scheme 9). Note that the latter reaction has been independently demonstrated.

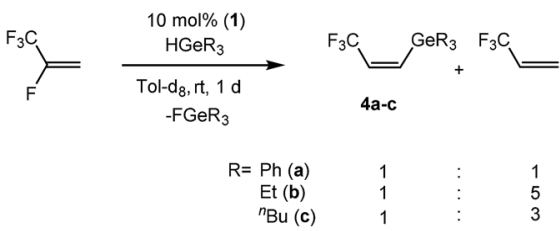

Scheme 8 Catalytic reaction of HFO-1234yf with tertiary germanes. 


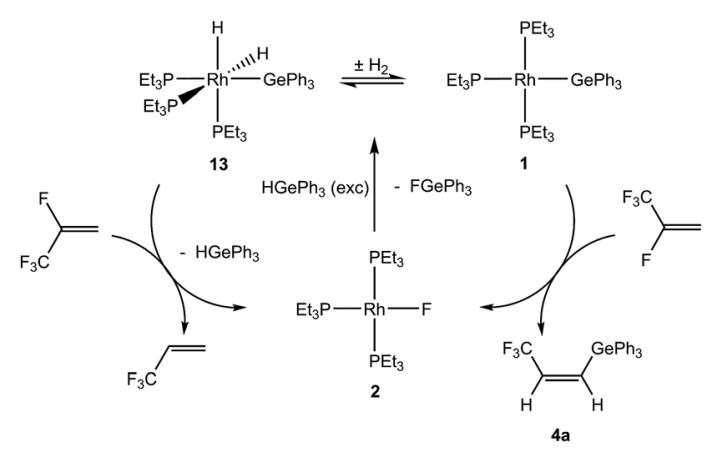

Paper

Scheme 9 Catalytic mechanism of HFO-1234yf with tertiary germanes.

When HFO-1234ze was used as a starting compound for catalytic conversions, full conversion of the germanes $\mathrm{HGeR}_{3}\left(\mathrm{R}=\mathrm{Ph},{ }^{n} \mathrm{Bu}\right)$ was also achieved after 1 day with $\left[\mathrm{Rh}\left(\mathrm{GePh}_{3}\right)\left(\mathrm{PEt}_{3}\right)_{3}\right]$ (1) $(10 \mathrm{~mol} \%)$ as catalyst. $\mathrm{HGeEt}_{3}$ required 2 days until full consumption was reached. However, the catalytic behavior of HFO-1234ze is in contrast to its isomer, HFO-1234yf, which seems to undergo more selective reactions. A hydrodefluorination reaction of HFO-1234ze to give 3,3,3-trifluoropropene occurred in every case, although the amount varies heavily depending on the germane used. For $\mathrm{HGePh}_{3}$, a subsequent hydrogermylation of 3,3,3-trifluoropropene gives a trifluoropropyl germane as the main product (Scheme 10). On the other hand, when $\mathrm{HGeEt}_{3}$ or $\mathrm{HGe}^{n} \mathrm{Bu}_{3}$ are the hydride source, the activation of 3,3,3-trifluoropropene is slower, leading to a lower selectivity of the reaction. Overall, up to seven different products have been identified including those from hydrogenation, hydrogermylation and $\mathrm{C}-\mathrm{F}$ activation of products of 3,3,3-trifluoropropene, as well as compounds $E-\mathrm{CF}_{3} \mathrm{CH}=\mathrm{CH}\left(\mathrm{GeR}_{3}\right)$ (12) $\left(\mathrm{R}=\mathrm{Ph}(\mathbf{a})\right.$, Et (b), $\left.{ }^{n} \mathrm{Bu}(\mathbf{c})\right)$ from the defluorogermylation of HFO-1234ze (Scheme 10).

Compounds 12 show distinguishable NMR spectroscopic resonances from their cis isomers. For example, compound 12c exhibits a doublet of doublets in the ${ }^{19} \mathrm{~F}$ NMR spectrum at $\delta-66.0 \mathrm{ppm}$ due to the coupling to the geminal and cis olefinic protons $\left({ }^{3} J_{\mathrm{F}, \mathrm{H}}=6,{ }^{4} J_{\mathrm{F}, \mathrm{H}}=2 \mathrm{~Hz}\right)$. These couplings are also observed in the

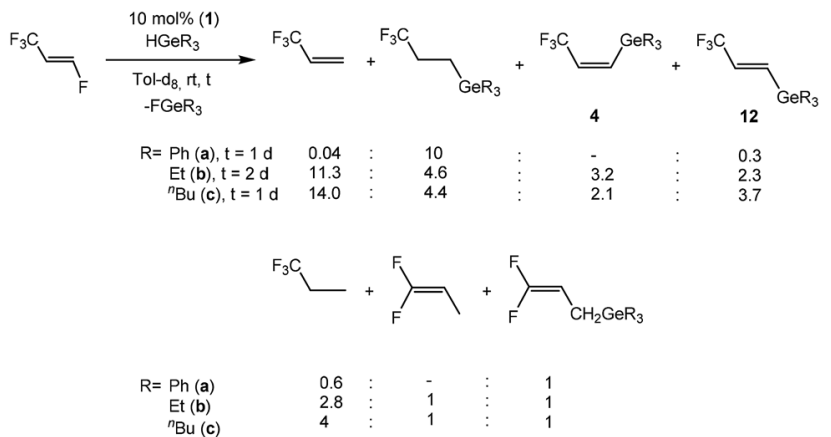

Scheme 10 Catalytic reactions of HFO-1234ze with tertiary germanes. 
Table 1 Catalytic studies with tetrafluoropropenes and $\mathrm{HSi}(\mathrm{OEt})_{3}$

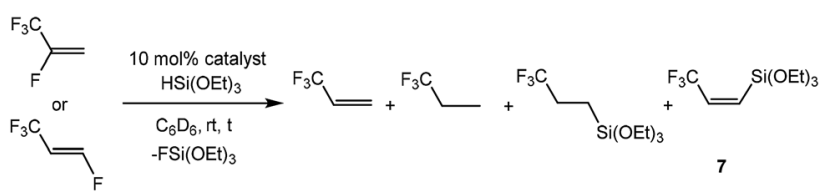

\begin{tabular}{llll}
\hline Catalyst & Olefin & Time $^{a}$ & Ratio of products $^{b}$ \\
\hline Complex 5 & HFO-1234yf & $8 \mathrm{~h}$ & $16.7: 4.6: 1.5: 1$ \\
Complex 8 & HFO-1234yf & $2 \mathrm{~h}$ & $16.8: 9: 1: 0$ \\
Complex 5 & HFO-1234ze & $8 \mathrm{~h}$ & $15: 8.4: 1: 0$ \\
Complex 8 & HFO-1234ze & $40 \mathrm{~min}$ & $9.5: 5.5: 1: 0$
\end{tabular}

${ }^{a}$ Time when full conversion was achieved based on the consumption of silane in ${ }^{1} \mathrm{H}$ NMR spectra. ${ }^{b}$ Based on ${ }^{19} \mathrm{~F}$ NMR measurements.

Table 2 Crystal data and structure refinement for $4 a$

$4 a$

Empirical formula

Formula wt

Temp. (K)

Wavelength $(\AA)$

Crystal system

Space group

$a(\AA)$

$b(\AA)$

$c(\AA)$

$\beta\left({ }^{\circ}\right)$

$V\left(\AA^{3}\right)$

Z

Density $\left(\mathrm{Mg} \mathrm{m}^{-3}\right)$

$\mu\left(\mathrm{mm}^{-1}\right)$

$F(000)$

Crystal size (mm)

$\theta$ range for data collection $\left(^{\circ}\right)$

Index ranges

No. of rflns collected

No. of indep rflns

Data completeness

Absorption correction

Max. and min. transmission

Refinement method

No. of data/restraints/params

Goodness of fit on $F^{2}$

$R$ indices $[I>2 \sigma(I)]$

$R$ indices (all data)

Largest diff. peak and hole $\left(\mathrm{e}^{-3}\right)$
$\mathrm{C}_{21} \mathrm{H}_{17} \mathrm{~F}_{3} \mathrm{Ge}$

398.93

$100(2)$

0.71073

Monoclinic

$P 2_{1} / c$

21.1522(11)

9.1254(4)

19.5533(9)

107.649(2)

3596.6(3)

8

1.474

1.732

1616

$0.360 \times 0.18 \times 0.12$

2.45-26.41

$-26 \leq h \leq 24$

$-11 \leq k \leq 11$

$-24 \leq l \leq 24$

36723

$7353[R($ int $)=0.0405]$

0.995

Multi-scan

0.614 and 0.745

Full matrix least-squares on $F^{2}$ $7353 / 0 / 451$

1.016

$R_{1}=0.0306, \mathrm{w} R_{2}=0.0671$

$R_{1}=0.0402, \mathrm{w} R_{2}=0.0706$

0.838 and -0.495 
${ }^{1} \mathrm{H}$ NMR spectrum for resonances at $\delta 6.08$ and $6.95 \mathrm{ppm}$, respectively, both as doublet of quartets with a proton-proton trans coupling constant of $18.9 \mathrm{~Hz}$. The chemical shifts and coupling constant values are similar to data found for olefins with hydrogen atoms in a trans position such as $E-\mathrm{CF}_{3} \mathrm{CH}=\mathrm{CH}(\mathrm{Bpin})$ and $E-\mathrm{CF}_{3} \mathrm{CH}=\mathrm{CH}\left(\mathrm{SiPh}_{3}\right)$. $^{3 d, 23}$

Finally, catalytic reactions involving the silane $\mathrm{HSi}(\mathrm{OEt})_{3}$ and the tetrafluoropropenes under study were performed using both $\left[\mathrm{Rh}\left\{\mathrm{Si}(\mathrm{OEt})_{3}\right\}\left(\mathrm{PEt}_{3}\right)_{3}\right]$ (5) and $\left[\mathrm{Rh}(\mathrm{H})\left(\mathrm{PEt}_{3}\right)_{3}\right](8)$ as a catalyst (see Table 1). When HFO-1234yf is reacted together with $\mathrm{HSi}(\mathrm{OEt})_{3}$ and $10 \mathrm{~mol} \%$ of complex 5, generation of 3,3,3trifluoropropene and 3,3,3-trifluoropropane together with small amounts of the olefin $\mathrm{Z}-\mathrm{CF}_{3} \mathrm{CH}=\mathrm{CH}\left(\mathrm{Si}(\mathrm{OEt})_{3}\right)(7)$ was observed, similar to the generation of vinyl germanes from tertiary germanes. However, in the case of silane and HFO-1234ze, a silylated olefin is not observed, but the silylated trifluoropropane is instead. When using complex $\mathbf{8}$ as catalyst under the same conditions, a faster consumption of silane is observed to provide similar products and ratios. In addition, reactions are generally more selective towards 3,3,3-trifluoropropene. The latter competes again with the tetrafluoropropenes as educt, leading also to the hydrogenation and the hydrosilylation products of 3,3,3-trifluoropropene.

\section{Conclusions}

In conclusion, it has been shown that the activity and selectivity of C-F bond activation reactions of the fluorinated olefins HFO-1234yf and HFO-1234ze at rhodium(I) complexes can be controlled by the anionic ligand. It was shown before that $\left[\mathrm{Rh}\left(\mathrm{GePh}_{3}\right)\left(\mathrm{PEt}_{3}\right)_{3}\right]$ (1) performs a $\mathrm{C}-\mathrm{F}$ bond activation towards hexafluoropropene and 3,3,3-trifluoropropene while $\left[\mathrm{Rh}\left(\mathrm{Si}(\mathrm{OEt})_{3}\right)\left(\mathrm{PEt}_{3}\right)_{3}\right](5)$ exhibits a different reactivity leading only to the coordination of the olefins. ${ }^{7, \mathbf{8 , 1 0}}$ It has been now demonstrated that both complexes show similar transformations with HFO-1234yf, yielding the rhodium fluorido complex 2 and the fluoroolefin $Z-\left(\mathrm{CF}_{3}\right) \mathrm{CH}=\mathrm{CH}(\mathrm{E})\left(\mathrm{E}=\mathrm{GePh}_{3}\right.$ (4a), $\mathrm{Si}(\mathrm{OEt})_{3}$ (7)). DFT calculations of the reaction mechanism indicate an initial $\mathrm{C}-\mathrm{H}$ oxidative addition of HFO-1234yf followed by C-E reductive elimination as a key step. For the silyl complex, the new olefin can subsequently undergo an insertion into the $\mathrm{Rh}-\mathrm{H}$ bond followed by a $\beta$-fluoride elimination to give 7 , whereas the computational results for a similar transformation in the case of the germyl system to afford $\mathbf{4 a}$ are not conclusive.

The reactivity of $\mathbf{1}$ and $\mathbf{5}$ differs with that previously reported for $\left[\mathrm{Rh}(\mathrm{H})\left(\mathrm{PEt}_{3}\right)_{3}\right](\mathbf{8})$, for which a reaction with HFO-1234yf yields the rhodium fluorido complex 2 and 3,3,3-trifluoropropene. On the other hand, the activation of HFO-1234ze proceeds in the same way for the three Rh starting compounds studied. Two different C-F activation pathways were identified, which involve either the generation of a $\mathrm{Rh}-\mathrm{C}$ bond and $\mathrm{FE}\left(\mathrm{E}=\mathrm{H}, \mathrm{GePh}_{3}, \mathrm{Si}(\mathrm{OEt})_{3}\right)$ or the formation of the rhodium fluorido complex 2 and trifluoropropene. For the rhodium silyl complex $\mathbf{5}$ and rhodium hydrido complex 8, initial olefin coordination was observed. Finally, while the stoichiometric reactions provide a germyl/silyl substituted olefin, the catalytic reactions are less selective, yielding functionalized building blocks based on a competition between C-F activation/hydrodefluorination reactions and germylation or silylation reactions. 


\section{Experimental}

\section{General procedures, methods and materials}

All experiments were carried out under an argon atmosphere using Schlenk techniques. Solvents were dried using the usual procedures ${ }^{24}$ and, prior to use, distilled under argon. The rhodium complexes $\left[\mathrm{Rh}\left(\mathrm{GePh}_{3}\right)\left(\mathrm{PEt}_{3}\right)_{3}\right](\mathbf{1}){ }^{8}\left[\mathrm{Rh}\left(\mathrm{Si}(\mathrm{OEt})_{3}\right)\left(\mathrm{PEt}_{3}\right)_{3}\right]$ $(5)^{9}$ and $\left[\mathrm{Rh}(\mathrm{H})\left(\mathrm{PEt}_{3}\right)_{3}\right](\mathbf{8})^{7 e}$ were prepared as described in the literature. All reagents were obtained from commercial sources. Complexes 2, 3 and 6 were identified by comparison of their analytical data with the literature., ${ }^{4,7, c, 18 a}$ Unless stated otherwise, NMR spectra were recorded at room temperature on a Bruker DPX-300 or a Bruker Avance 300 spectrometer using the solvent as the internal lock. ${ }^{1} \mathrm{H}$ and ${ }^{13} \mathrm{C}$ $\left\{{ }^{1} \mathrm{H}\right\}$ signals are referred to residual solvent signals, those of ${ }^{31} \mathrm{P}\left\{{ }^{1} \mathrm{H}\right\}$ to $85 \% \mathrm{H}_{3} \mathrm{PO}_{4}$ and the ${ }^{19} \mathrm{~F}$ NMR spectra to external $\mathrm{CFCl}_{3} .{ }^{1} \mathrm{H}$ and ${ }^{13} \mathrm{C}\left\{{ }^{1} \mathrm{H}\right\}$ NMR signal assignments were supported by ${ }^{1} \mathrm{H}-{ }^{1} \mathrm{H}$ COSY, ${ }^{19} \mathrm{~F}-{ }^{1} \mathrm{H}$ COSY, ${ }^{19} \mathrm{~F}-{ }^{19} \mathrm{~F}$ COSY, ${ }^{31} \mathrm{P}-{ }^{31} \mathrm{P}$ COSY, ${ }^{1} \mathrm{H}-{ }^{13} \mathrm{C}$ HMQC, ${ }^{1} \mathrm{H}-{ }^{13} \mathrm{C}$ HMBC and ${ }^{19} \mathrm{~F}^{13} \mathrm{C}$ HMBC NMR experiments.

\section{X-ray diffraction analysis}

Suitable crystals for X-ray crystallography of $Z-\mathrm{CF}_{3} \mathrm{CH}=\mathrm{CH}\left(\mathrm{GePh}_{3}\right)(\mathbf{4 a})$ were obtained from the reaction mixture of $\left[\mathrm{Rh}(\mathrm{F})\left(\mathrm{PEt}_{3}\right)_{3}\right](2),\left[\mathrm{Rh}\left\{(E)-\mathrm{C}\left(\mathrm{CF}_{3}\right)=\mathrm{CHF}\right\}\left(\mathrm{PEt}_{3}\right)_{3}\right](3)$ and the germylated olefin 4a. Recrystallization of a saturated $n$-hexane solution of $\mathbf{4 a}$ at $243 \mathrm{~K}$ was performed in an $n$-heptane solution at room temperature by slow evaporation of the solvent. Crystallographic data were collected on a Bruker D8 Venture diffractometer at $100 \mathrm{~K}$. The structures were solved by intrinsic phasing (SHELXT$2013)^{25}$ and refined by full matrix least-squares procedures based on $F^{2}$ with all measured reflections (SHELXL-2013). ${ }^{26}$ The SADABS program ${ }^{27}$ was used for multiscan absorption corrections. All non-hydrogen atoms were refined with anisotropic displacement parameters. Hydrogen atoms were included in idealized positions and refined using a riding model. Crystal data and structural refinement details for complex 4a are given in Table 2. CCDC 1912055 contains the crystallographic data. $\dagger$

\section{Computational details}

Structure optimizations for all compounds except 10 (see below) were carried out with the Turbomole program, version 7.3.0, ${ }^{28}$ at the DFT-BP86 ${ }^{29}$ level of theory in conjunction with all-electron def2-SVP basis sets for the main group atoms $(\mathrm{H}, \mathrm{C}$, $\mathrm{O}, \mathrm{F}, \mathrm{Si}, \mathrm{P}, \mathrm{Ge})^{30}$ and a quasirelativistic energy-adjusted small-core pseudopotential (RECP) with a def2-SVP valence basis set for rhodium, ${ }^{31}$ using the resolution-of-identity $(\mathrm{RI})^{31 a, 32}$ approximation as well as an atom-pairwise correction for dispersion forces via Grimme's D3 model with Becke-Johnson damping (BJ) ${ }^{33}$ (RI-BP86-D3(BJ)/def2-SVP level). Solvent effects have been taken into account using the $\mathrm{COSMO}^{34}$ continuum solvent model, employing toluene with a dielectric constant of $\varepsilon=2.3741$. The structures of the possible isomers of complex $f a c$ - $\left[\mathrm{RhH}\left(\eta^{2}-\mathrm{CHF}=\mathrm{CHCF}_{3}\right)\left(\mathrm{PEt}_{3}\right)_{3}\right](\mathbf{1 0})$ were optimized in the gas phase using the Gaussian 09 (Revision D.01) program package ${ }^{35}$ at the B3LYP-D3(BJ) level, employing an RECP with associated cc-pVDZ valence basis set for rhodium $^{36}$ and all-electron cc-pVDZ basis sets for the lighter atoms. ${ }^{37}$ All structures were characterized as true minima or transition states by analytical harmonic vibrational frequency analyses. Based on the frequency analyses, Gibbs free activation and reaction energies at $298.15 \mathrm{~K}$ and $0.1 \mathrm{MPa}$ were evaluated 
within the rigid-rotor and harmonic-oscillator approximations. The calculated relative energy of the isomers of $\mathbf{1 0}$ is based on zero-point vibrational energy corrected total electronic energies from optimization in the gas phase. Cartesian coordinates for all optimized structures can be found in the ESI. $\dagger$

\section{Reaction of HFO-1234yf with $\left[\mathrm{Rh}\left(\mathrm{GePh}_{3}\right)\left(\mathrm{PEt}_{3}\right)_{3}\right](1)$}

In a Young NMR tube $\left[\mathrm{Rh}\left(\mathrm{GePh}_{3}\right)\left(\mathrm{PEt}_{3}\right)_{3}\right](1)(18.2 \mathrm{mg}, 0.024 \mathrm{mmol})$ was dissolved in $\mathrm{C}_{6} \mathrm{D}_{6}$ or toluene- $d_{8}(0.4 \mathrm{~mL})$. The solution was cooled to $77 \mathrm{~K}$, degassed in vacuo, and pressurized with HFO-1234yf to 0.2 bar. After warming up to room temperature, the NMR spectroscopic data for the reaction mixture revealed after $10 \mathrm{~min}$ the complete conversion of 1 into $\left[\mathrm{Rh}(\mathrm{F})\left(\mathrm{PEt}_{3}\right)_{3}\right](2)$ and $\left[\mathrm{Rh}\left\{(E)-\mathrm{C}\left(\mathrm{CF}_{3}\right)=\mathrm{CHF}\right\}\left(\mathrm{PEt}_{3}\right)_{3}\right](3)$ in a $85: 15$ ratio, as well as a small amount of an unknown rhodium complex that evolves into complexes 2 and 3 after 1 day. The formation of $Z-\left(\mathrm{CF}_{3}\right) \mathrm{CH}=\mathrm{CH}\left(\mathrm{GePh}_{3}\right)$ (4a) and traces of trifluoropropene and another unknown $\mathrm{CF}_{3}$-containing derivative (10.7: 1.8: 1 ratio, respectively) as well as fluorogermane were also observed. Analytical data for $4 a:{ }^{1} \mathrm{H}$ NMR (300.1 MHz, toluene- $\left.d_{8}\right): \delta=7.46(\mathrm{~m}, 6 \mathrm{H}, \mathrm{Ph}) ; 7.13(\mathrm{~m}, 9 \mathrm{H}, \mathrm{Ph}) ; 6.45(\mathrm{dq}$, $\left.{ }^{3} J_{\mathrm{H}-\mathrm{H}}=14.3 \mathrm{~Hz},{ }^{4} J_{\mathrm{H}-\mathrm{F}}=0.34 \mathrm{~Hz}, 1 \mathrm{H},=\mathrm{CHGePh}\right) ; 6.285\left(\mathrm{dq},{ }^{3} J_{\mathrm{H}-\mathrm{H}}=14.3,{ }^{3} J_{\mathrm{H}-}\right.$ $\mathrm{F}=7.87 \mathrm{~Hz}, 1 \mathrm{H},=\mathrm{CH}) \mathrm{ppm}$. The data of the olefinic protons correspond to their simulation with the gNMR software. ${ }^{38}{ }^{19} \mathrm{~F}$ NMR $\left(282.4 \mathrm{MHz}\right.$, toluene- $\left.d_{8}\right)$ : $\delta=-62.2\left(\mathrm{~d},{ }^{3} J_{\mathrm{F}-\mathrm{H}}=7 \mathrm{~Hz}, 3 \mathrm{~F}, \mathrm{C} F_{3}\right) \mathrm{ppm} .{ }^{13} \mathrm{C}\left\{{ }^{1} \mathrm{H}\right\}$ NMR $\left(75.5 \mathrm{MHz}\right.$, toluene- $\left.d_{8}\right)$ : $\delta=139.0\left(\mathrm{q},{ }^{3} J_{\mathrm{C}-\mathrm{F}}=8 \mathrm{~Hz},=C \mathrm{GePh}_{3}\right) ; 135.2(\mathrm{~s}, \mathrm{Ph}) ; 135.0(\mathrm{~s}, \mathrm{Ph}) ; 134.2\left(\mathrm{q},{ }^{2} J_{\mathrm{C}-}\right.$ $\mathrm{F}=34 \mathrm{~Hz},=C \mathrm{H}) ; 129.5(\mathrm{~s}, \mathrm{Ph}) ; 128.6(\mathrm{~s}, \mathrm{Ph}) ; 122.8\left(\mathrm{q},{ }^{1} J_{\mathrm{C}-\mathrm{F}}=273 \mathrm{~Hz}, C \mathrm{~F}_{3}\right) \mathrm{ppm}$.

\section{Reaction of HFO-1234yf with $\left[\operatorname{Rh}\left\{\operatorname{Si}(\mathrm{OEt})_{3}\right\}\left(\mathrm{PEt}_{3}\right)_{3}\right](5)$}

In a Young NMR tube $\left[\mathrm{Rh}\left\{\mathrm{Si}(\mathrm{OEt})_{3}\right\}\left(\mathrm{PEt}_{3}\right)_{3}\right](5)(20.4 \mathrm{mg}, 0.033 \mathrm{mmol})$ was dissolved in $\mathrm{C}_{6} \mathrm{D}_{6}$ or toluene- $d_{8}(0.5 \mathrm{~mL})$. The solution was cooled to $77 \mathrm{~K}$, degassed in vacuo, and pressurized with HFO-1234yf to 0.3 bar. After warming up to room temperature, the NMR spectroscopic data for the reaction mixture revealed after 10 min the complete conversion of 5 into $\left[\mathrm{Rh}(\mathrm{F})\left(\mathrm{PEt}_{3}\right)_{3}\right](2)$ and $\left[\mathrm{Rh}\left(\mathrm{PEt}_{3}\right)_{4}\right]^{+}(6)$ in a $90: 10$ ratio, as well as the formation of $Z-\left(\mathrm{CF}_{3}\right) \mathrm{CH}=\mathrm{CH}\left(\mathrm{Si}(\mathrm{OEt})_{3}\right)(7), 3,3,3$-trifluoropropene and traces of fluorosilane. When the mixture was reacted for $18 \mathrm{~h}$, NMR spectroscopic data revealed the formation of $\left[\mathrm{Rh}\left\{(E)-\mathrm{C}\left(\mathrm{CF}_{3}\right)=\mathrm{CHF}\right\}\left(\mathrm{PEt}_{3}\right)_{3}\right]$ (3), complex 6 and an unidentified rhodium complex in a 58:29:13 ratio. Analytical data for $Z-\left(\mathrm{CF}_{3}\right) \mathrm{CH}=\mathrm{CH}\left(\mathrm{Si}(\mathrm{OEt})_{3}\right)(7):{ }^{1} \mathrm{H}$ NMR $\left(300.1 \mathrm{MHz}\right.$, toluene- $\left.d_{8}\right)$ : $\delta=6.071\left(\mathrm{dq},{ }^{3} J_{\mathrm{H}-\mathrm{H}}=15.54,{ }^{3} J_{\mathrm{H}-\mathrm{F}}=7.95 \mathrm{~Hz}, 1 \mathrm{H},=\mathrm{CH}\right) ; 5.958\left(\mathrm{~d},{ }^{3} J_{\mathrm{H}-\mathrm{H}}=15.54\right.$, $\left.{ }^{4} J_{\mathrm{H}-\mathrm{F}}=-0.22 \mathrm{~Hz}, 1 \mathrm{H},=\mathrm{CHSi}(\mathrm{OEt})_{3}\right) ; 4.13\left(\mathrm{q},{ }^{3} J_{\mathrm{H}-\mathrm{H}}=7.0 \mathrm{~Hz}, \mathrm{OCH}_{2} \mathrm{CH}_{3}\right) ; 1.40-1.52$ $\left(\mathrm{m}, 9 \mathrm{H}\right.$, overlapped with $\mathrm{PEt}_{3}$ signals of 2 and $\left.6, \mathrm{OCH}_{2} \mathrm{CH}_{3}\right) ; 3.78\left(\mathrm{q},{ }^{3} \mathrm{~J}_{\mathrm{H}-\mathrm{H}}=6.9 \mathrm{~Hz}\right.$, $\left.6 \mathrm{H}, \mathrm{OCH}_{2} \mathrm{CH}_{3}\right) \mathrm{ppm}$. The olefinic protons correspond to their simulation with the gNMR software.$^{38}{ }^{19} \mathrm{~F}$ NMR $\left(282.4 \mathrm{MHz}\right.$, toluene- $\left.d_{8}\right): \delta=-63.9\left(\mathrm{~d},{ }^{2} J_{\mathrm{F}-\mathrm{H}}=8 \mathrm{~Hz}, 3 \mathrm{~F}\right.$, $\mathrm{C}_{3}$ ) ppm. ${ }^{1} \mathrm{H},{ }^{29} \mathrm{Si}$ HMBC NMR (59.6 MHz, toluene- $\left.d_{8}, 263 \mathrm{~K}\right): \delta=-69.8$ (s) ppm.

\section{Reaction of HFO-1234ze with $\left[\mathrm{Rh}(\mathrm{H})\left(\mathrm{PEt}_{3}\right)_{3}\right](8)$}

In a Young NMR tube $\left[\mathrm{Rh}(\mathrm{H})\left(\mathrm{PEt}_{3}\right)_{3}\right](8)(50.1 \mathrm{mg}, 0.109 \mathrm{mmol})$ was dissolved in toluene- $d_{8}(0.5 \mathrm{~mL})$. The solution was cooled to $77 \mathrm{~K}$, degassed in vacuo, and pressurized with HFO-1234ze to 0.2 bar. After warming up to $213 \mathrm{~K}$, the NMR spectroscopic data for the reaction mixture revealed the complete conversion of $\left[\mathrm{Rh}(\mathrm{H})\left(\mathrm{PEt}_{3}\right)_{3}\right]$ into $f a c-\left[\mathrm{RhH}\left(\eta^{2}-\mathrm{CHF}=\mathrm{CHCF}_{3}\right)\left(\mathrm{PEt}_{3}\right)_{3}\right](\mathbf{1 0})$. The complex is only 
stable up to $283 \mathrm{~K}$, when it fully converts into the rhodium fluorido complex $\left[\mathrm{Rh}(\mathrm{F})\left(\mathrm{PEt}_{3}\right)_{3}\right](2)$ and $\left[\mathrm{Rh}\left\{(E)-\mathrm{CH}=\mathrm{CHCF}_{3}\right\}\left(\mathrm{PEt}_{3}\right)_{3}\right](\mathbf{9})$ in a $70: 30$ ratio, respectively, with traces of an unknown rhodium complex. In addition, formation of HF and 3,3,3-trifluoropropene was also observed. Analytical data for 10: ${ }^{1} \mathrm{H}$ NMR (300.1 MHz, toluene- $\left.d_{8}, 243 \mathrm{~K}\right): \delta=6.40\left(\mathrm{dddm},{ }^{2} J_{\mathrm{H}-\mathrm{F}}=69.5,{ }^{3} J_{\mathrm{H}-\mathrm{P}}=10.7,{ }^{3} J_{\mathrm{H}-\mathrm{H}}=\right.$ $4.9 \mathrm{~Hz}, 1 \mathrm{H}, \mathrm{CHF}) ; 2.88\left(\mathrm{~m} \mathrm{br}\right.$, dqdd in ${ }^{1} \mathrm{H}\left\{{ }^{31} \mathrm{P}\right\}$ NMR spectrum ${ }^{3} J_{\mathrm{H}-\mathrm{F}}=19.2,{ }^{3} J_{\mathrm{H}-\mathrm{F}}=$ $\left.9.8,{ }^{3} J_{\mathrm{H}-\mathrm{H}}=4.9,{ }^{2} J_{\mathrm{H}-\mathrm{Rh}}=1.9 \mathrm{~Hz}, 1 \mathrm{H}, \mathrm{CHCF}_{3}\right) ; 1.70-1.50\left(\mathrm{~m}, 6 \mathrm{H}, \mathrm{PCH}_{2} \mathrm{CH}_{3}\right) ; 1.50-$ $1.23\left(\mathrm{~m}, 12 \mathrm{H}, \mathrm{PCH}_{2} \mathrm{CH}_{3}\right) ; 1.02-0.86\left(\mathrm{~m}, 18 \mathrm{H}, \mathrm{PCH}_{2} \mathrm{CH}_{3}\right) ; 0.85-0.65(\mathrm{~m}, 9 \mathrm{H}$, $\left.\mathrm{PCH}_{2} \mathrm{CH}_{3}\right) ;-14.54\left(\mathrm{dtd},{ }^{2} J_{\mathrm{H}-\mathrm{P}}=156.0,{ }^{2} J_{\mathrm{H}-\mathrm{P}} \approx{ }^{2} J_{\mathrm{H}-\mathrm{P}}=18.9,{ }^{1} J_{\mathrm{H}-\mathrm{Rh}}=10.9 \mathrm{~Hz}, 1 \mathrm{H}\right.$, $\mathrm{Rh} H$ ) ppm. Although the shifts correspond to the experiments at $243 \mathrm{~K}$, the ${ }^{1} \mathrm{H}$ NMR spectra at different temperatures were analyzed to obtain all the coupling constant data. ${ }^{19} \mathrm{~F}$ NMR $\left(282 \mathrm{MHz}\right.$, toluene- $\left.d_{8}, 243 \mathrm{~K}\right) \delta=-53.6$ (ddt br, ${ }^{4} J_{\mathrm{F}-\mathrm{P}}=17$, $\left.{ }^{3} J_{\mathrm{F}-\mathrm{H}}=10,{ }^{4} J_{\mathrm{F}-\mathrm{P}} \approx{ }^{4} J_{\mathrm{F}-\mathrm{F}}=5 \mathrm{~Hz}, 3 \mathrm{~F}, \mathrm{C} F_{3}\right) ;-174.4\left(\mathrm{~m}\right.$, dddp in ${ }^{19} \mathrm{~F}\left\{{ }^{1} \mathrm{H}\right\} \mathrm{NMR}$ spectrum ${ }^{3} J_{\mathrm{F}-\mathrm{P}}=49 \mathrm{~Hz},{ }^{3} J_{\mathrm{F}-\mathrm{P}}=34 \mathrm{~Hz},{ }^{3} J_{\mathrm{F}-\mathrm{P}}=17 \mathrm{~Hz},{ }^{4} J_{\mathrm{F}-\mathrm{F}} \approx{ }^{2} J_{\mathrm{F}-\mathrm{Rh}}=4 \mathrm{~Hz}, 1 \mathrm{~F}$, $\mathrm{CH} F)$ ppm. ${ }^{31} \mathrm{P}\left\{{ }^{1} \mathrm{H}\right\}$ NMR $\left(121.5 \mathrm{MHz}\right.$, toluene- $\left.d_{8}, 243 \mathrm{~K}\right): \delta=19.3\left(\right.$ dtqd, ${ }^{1} J_{\mathrm{P}-\mathrm{Rh}}=$ 133.6, ${ }^{2} J_{\mathrm{P}-\mathrm{P}} \approx{ }^{2} J_{\mathrm{P}-\mathrm{P}}=26.5,{ }^{4} J_{\mathrm{P}-\mathrm{F}}=16.8,{ }^{3} J_{\mathrm{P}-\mathrm{F}}=16.2 \mathrm{~Hz}, 1 \mathrm{P}, \mathrm{PEt}_{3}$ trans to $\left.\mathrm{CHCF}_{3}\right)$; 10.2 (ddt, ${ }^{1} J_{\mathrm{P}-\mathrm{Rh}}=110.5,{ }^{3} J_{\mathrm{P}-\mathrm{F}}=49.3,{ }^{2} J_{\mathrm{P}-\mathrm{P}} \approx{ }^{2} J_{\mathrm{P}-\mathrm{P}}=26.5,1 \mathrm{P}, \mathrm{PEt}_{3}$ trans to CHF); $6.1\left(\mathrm{ddtm},{ }^{1} J_{\mathrm{P}-\mathrm{Rh}}=96.1,{ }^{3} J_{\mathrm{P}-\mathrm{F}}=39.4,{ }^{2} J_{\mathrm{P}-\mathrm{P}} \approx{ }^{2} J_{\mathrm{P}-\mathrm{P}}=26.5 \mathrm{~Hz}, 1 \mathrm{P}, \mathrm{PEt}_{3}\right.$ trans to $\mathrm{H})$ ppm. ${ }^{1} \mathrm{H},{ }^{13} \mathrm{C}$ HMQC NMR (75.5 MHz, toluene- $\left.d_{8}, 213 \mathrm{~K}\right): \delta=99\left(\mathrm{dd},{ }^{1} J_{\mathrm{C}-\mathrm{F}}=\right.$ $\left.243,{ }^{1} J_{\mathrm{C}-\mathrm{Rh}}=75 \mathrm{~Hz}, C \mathrm{HF}\right), 28\left(\mathrm{~m},{ }^{1} J_{\mathrm{C}-\mathrm{Rh}}=45 \mathrm{~Hz}, C \mathrm{HCF}_{3}\right) \mathrm{ppm}$. All the signals except for the ethyl groups have been simulated with the gNMR software (see $\mathrm{ESI} \dagger){ }^{38}$

\section{Reaction of HFO-1234ze with $\left[\mathrm{Rh}\left(\mathrm{GePh}_{3}\right)\left(\mathrm{PEt}_{3}\right)_{3}\right](1)$}

In a Young NMR tube $\left[\mathrm{Rh}\left(\mathrm{GePh}_{3}\right)\left(\mathrm{PEt}_{3}\right)_{3}\right](\mathbf{1})(21.3 \mathrm{mg}, 0.028 \mathrm{mmol})$ was dissolved in $\mathrm{C}_{6} \mathrm{D}_{6}(0.5 \mathrm{~mL})$. The solution was cooled to $77 \mathrm{~K}$, degassed in vacuo, and pressurized with HFO-1234ze to 0.2 bar. After warming up to room temperature, the NMR spectroscopic data for the reaction mixture revealed after $16 \mathrm{~h}$ the complete conversion of 1 into $\left[\mathrm{Rh}(\mathrm{F})\left(\mathrm{PEt}_{3}\right)_{3}\right](2),\left[\mathrm{Rh}\left\{(E)-\mathrm{CH}=\mathrm{CH}\left(\mathrm{CF}_{3}\right)\right\}\left(\mathrm{PEt}_{3}\right)_{3}\right](\mathbf{9})$ and an unidentified rhodium complex in a $54: 24: 22$ mole ratio, as well as the formation of 3,3,3-trifluoropropene, $\left(\mathrm{Ph}_{3} \mathrm{Ge}\right) \mathrm{CH}_{2} \mathrm{CH}=\mathrm{CF}_{2}$, fluorogermane and some unknown compounds.

\section{Reaction of HFO-1234ze with $\left[\mathrm{Rh}\left\{\mathrm{Si}(\mathrm{OEt})_{3}\right\}\left(\mathrm{PEt}_{3}\right)_{3}\right](5)$}

In a Young NMR tube $\left[\mathrm{Rh}\left\{\mathrm{Si}(\mathrm{OEt})_{3}\right\}\left(\mathrm{PEt}_{3}\right)_{3}\right](5)(30 \mathrm{mg}, 0.048 \mathrm{mmol})$ was dissolved in $\mathrm{C}_{6} \mathrm{D}_{6}(0.5 \mathrm{~mL})$. The solution was cooled to $77 \mathrm{~K}$, degassed in vacuo, and pressurized with HFO-1234ze to 0.2 bar. After warming up to room temperature, the NMR spectroscopic data for the reaction mixture revealed after $10 \mathrm{~min}$ the complete conversion of 5 into $\left[\mathrm{Rh}(\mathrm{F})\left(\mathrm{PEt}_{3}\right)_{3}\right](2)$, the coordination product $\left[\mathrm{Rh}\left\{\mathrm{Si}(\mathrm{OEt})_{3}\right\}\left(\eta^{2}-\mathrm{CHF}=\mathrm{CHCF}_{3}\right)\left(\mathrm{PEt}_{3}\right)_{2}\right] \quad(\mathbf{1 1})$ and an unknown rhodium(I) complex in a $18: 71: 11$ mole ratio, as well as the release of $\mathrm{PEt}_{3}$. The reaction mixture evolved after $1 \mathrm{~d}$ to give the complexes $\left[\mathrm{Rh}\left\{(E)-\mathrm{CH}=\mathrm{CH}\left(\mathrm{CF}_{3}\right)\right\}\left(\mathrm{PEt}_{3}\right)_{3}\right]$ (9), $\left[\mathrm{Rh}\left(\mathrm{PEt}_{3}\right)_{4}\right]^{+}(6)$ and an unidentified rhodium complex in a $22: 48: 30$ mole ratio, as well as the formation of 3,3,3-trifluoropropene and fluorosilane. Analytical data for 11: ${ }^{1} \mathrm{H}$ NMR $\left(300.1 \mathrm{MHz}, \mathrm{C}_{6} \mathrm{D}_{6}\right): \delta=1.10\left(\mathrm{t},{ }^{3} \mathrm{~J}_{\mathrm{H}-\mathrm{H}}=7.1 \mathrm{~Hz}\right.$, $\left.9 \mathrm{H}, \mathrm{Si}\left(\mathrm{OCH}_{2} \mathrm{CH}_{3}\right)_{3}\right) ; 3.4\left(\mathrm{~m} \mathrm{br}, 1 \mathrm{H}, \mathrm{CF}_{3} \mathrm{CH}\right) ; 3.76$ (pseudo quint, ${ }^{3} J_{\mathrm{H}-\mathrm{H}} \approx{ }^{4} J_{\mathrm{H}-\mathrm{Rh}}=$ $\left.6.9 \mathrm{~Hz}, 6 \mathrm{H}, \mathrm{Si}\left(\mathrm{OCH}_{2} \mathrm{CH}_{3}\right)_{3}\right) ; 6.79\left(\mathrm{~d} \mathrm{br},{ }^{2} \mathrm{~J}_{\mathrm{H}-\mathrm{F}}=64 \mathrm{~Hz}, 1 \mathrm{H}, \mathrm{CFH}\right) \mathrm{ppm} .{ }^{1} \mathrm{H} \mathrm{NMR}$ (300.1 MHz, toluene- $\left.d_{8}, 233 \mathrm{~K}\right): \delta=6.67\left(\mathrm{dm}\right.$, ddd in ${ }^{1} \mathrm{H}\left\{{ }^{31} \mathrm{P}\right\}$ and pseudo td in 
${ }^{1} \mathrm{H}\left\{{ }^{19} \mathrm{~F}\right\}$ NMR spectra, ${ }^{2} J_{\mathrm{H}-\mathrm{F}}=63.4,{ }^{3} J_{\mathrm{H}-\mathrm{H}} \approx{ }^{3} J_{\mathrm{H}-\mathrm{P}}=6.3,{ }^{2} J_{\mathrm{H}-\mathrm{Rh}}=2.5 \mathrm{~Hz}, 1 \mathrm{H}$, $\mathrm{CFH}) ; 3.70\left(\mathrm{~m},{ }^{3} J_{\mathrm{H}-\mathrm{H}}=7.0 \mathrm{~Hz}, 6 \mathrm{H}, \mathrm{Si}\left(\mathrm{OCH}_{2} \mathrm{CH}_{3}\right)_{3}\right) ; 3.32\left(\mathrm{~m}\right.$, dqd in ${ }^{1} \mathrm{H}\left\{{ }^{31} \mathrm{P}\right\}$ NMR spectrum, $\left.{ }^{3} J_{\mathrm{H}-\mathrm{F}}=17.5,{ }^{3} J_{\mathrm{H}-\mathrm{F}}=11.8,{ }^{3} J_{\mathrm{H}-\mathrm{H}}=6.3 \mathrm{~Hz}, 1 \mathrm{H}, \mathrm{CF}_{3} \mathrm{CH}\right) ; 1.09\left(\mathrm{t},{ }^{3} J_{\mathrm{H}-}\right.$ $\left.\mathrm{H}=7.0 \mathrm{~Hz}, 9 \mathrm{H}, \mathrm{Si}\left(\mathrm{OCH}_{2} \mathrm{CH}_{3}\right)_{3}\right)$ ppm. ${ }^{19} \mathrm{~F} \mathrm{NMR}\left(282.4 \mathrm{MHz}, \mathrm{C}_{6} \mathrm{D}_{6}\right): \delta=-51.2(\mathrm{~s} \mathrm{br}$, $\left.3 \mathrm{~F}, \mathrm{C} F_{3}\right) ;-185.5(\mathrm{~s} \mathrm{br}, 1 \mathrm{~F},=\mathrm{C} F \mathrm{H}) \mathrm{ppm} .{ }^{19} \mathrm{~F} \mathrm{NMR}\left(282.4 \mathrm{MHz}\right.$, toluene- $\left.d_{8}, 233 \mathrm{~K}\right): \delta=$ $-51.3\left(\mathrm{ddt},{ }^{4} J_{\mathrm{F}-\mathrm{P}}=18,{ }^{3} J_{\mathrm{F}-\mathrm{H}}=12,{ }^{4} J_{\mathrm{F}-\mathrm{H}} \approx{ }^{4} J_{\mathrm{F}-\mathrm{F}}=3 \mathrm{~Hz}, 3 \mathrm{~F}, \mathrm{C} F_{3}\right) ;-185.5\left(\mathrm{ddtm},{ }^{2} J_{\mathrm{F}-}\right.$ $\left.\mathrm{H}=63,{ }^{3} J_{\mathrm{F}-\mathrm{P}}=36,{ }^{3} J_{\mathrm{F}-\mathrm{H}} \approx{ }^{3} J_{\mathrm{F}-\mathrm{P}}=17 \mathrm{~Hz}, 1 \mathrm{~F},=\mathrm{C} F \mathrm{H}\right) \mathrm{ppm} .{ }^{31} \mathrm{P}\left\{{ }^{1} \mathrm{H}\right\} \mathrm{NMR}(121.5 \mathrm{MHz}$, $\left.\mathrm{C}_{6} \mathrm{D}_{6}\right): \delta=18.0\left(\mathrm{dm},{ }^{1} J_{\mathrm{P}-\mathrm{Rh}}=127.7 \mathrm{~Hz}, 1 \mathrm{P}\right) ; 21.5\left(\mathrm{dm},{ }^{1} J_{\mathrm{P}-\mathrm{Rh}}=133.6 \mathrm{~Hz}, 1 \mathrm{P}\right) \mathrm{ppm} .{ }^{31} \mathrm{P}$ $\left\{{ }^{1} \mathrm{H}\right\}$ NMR $\left(121.5 \mathrm{MHz}\right.$, toluene- $\left.d_{8}, 233 \mathrm{~K}\right): \delta=19.1\left(\mathrm{ddd},{ }^{1} J_{\mathrm{P}-\mathrm{Rh}}=123.2,{ }^{3} J_{\mathrm{P}-\mathrm{F}}=36.3\right.$, ${ }^{2} J_{\mathrm{P}-\mathrm{P}}=22.7 \mathrm{~Hz}, 1 \mathrm{P}, \mathrm{PEt}_{3}$ trans to CHF); 21.1 (ddqd, ${ }^{1} J_{\mathrm{P}-\mathrm{Rh}}=133.9,{ }^{2} J_{\mathrm{P}-\mathrm{P}}=22.7,{ }^{4} J_{\mathrm{P}-}$ $\mathrm{F}=18.4,{ }^{3} J_{\mathrm{P}-\mathrm{F}}=15.8 \mathrm{~Hz}, 1 \mathrm{P}, \mathrm{PEt}_{3}$ trans to $\left.\mathrm{CHCF}_{3}\right) \mathrm{ppm}$. Phosphorus resonances have been simulated with the gNMR software. ${ }^{38}{ }^{1} \mathrm{H},{ }^{29} \mathrm{Si} \mathrm{HMBC}$ NMR $(59.6 \mathrm{MHz}$, toluene- $\left.d_{8}\right): \delta=-54.2\left(\mathrm{~d},{ }^{1} J_{\mathrm{Si}-\mathrm{Rh}} \approx 140 \mathrm{~Hz}\right) \mathrm{ppm}$.

\section{General procedure for the catalytic conversion of the fluorinated olefins using $\left[\mathrm{Rh}\left(\mathrm{GePh}_{3}\right)\left(\mathrm{PEt}_{3}\right)_{3}\right](1)$ and tertiary germanes}

In a Young NMR tube $\left[\mathrm{Rh}\left(\mathrm{GePh}_{3}\right)\left(\mathrm{PEt}_{3}\right)_{3}\right](\mathbf{1})(10.0 \mathrm{mg}, 0.013 \mathrm{mmol})$ was dissolved in toluene- $d_{8}(0.4 \mathrm{~mL})$ and $\mathrm{HGeR}_{3}(0.13 \mathrm{mmol})$ was added to the solution. The solution was cooled to $77 \mathrm{~K}$, degassed in vacuo, and pressurized with HFO-1234yf or HFO-1234ze to 0.2 bar. After warming up to room temperature the reaction was monitored using NMR spectroscopy. After the reaction time at room temperature the ${ }^{1} \mathrm{H}$ and ${ }^{19} \mathrm{~F}$ NMR spectroscopic data revealed the complete conversion of $\mathrm{HGeR}_{3}$, and the formation of the corresponding fluorogermane as well as the products.

Catalytic conversion of HFO-1234yf with $\mathbf{H G e P h}_{3}$. Reaction of 1 (10 mol\%), $\mathrm{HGePh}_{3}(40.1 \mathrm{mg}, 0.13 \mathrm{mmol})$ and $0.2 \mathrm{bar}$ of HFO-1234yf for $1 \mathrm{~d}$ at room temperature yielded $Z-\left(\mathrm{CF}_{3}\right) \mathrm{CH}=\mathrm{CH}\left(\mathrm{GePh}_{3}\right)$ (4a), $\mathrm{CH}_{2}=\mathrm{CHCF}_{3}, \mathrm{Ph}_{3} \mathrm{GeCH}_{2} \mathrm{CH}_{2} \mathrm{CF}_{3}, E$ $\left(\mathrm{CF}_{3}\right) \mathrm{CH}=\mathrm{CH}\left(\mathrm{GePh}_{3}\right)\left(\right.$ 12a) and $\mathrm{CF}_{3} \mathrm{CH}_{2} \mathrm{CH}_{3}$ in a ratio of $1: 1: 0.5: 0.1: 0.05$.

Catalytic conversion of HFO-1234yf with HGeEt $_{3}$. Reaction of 1 (10 mol\%), $\mathrm{HGeEt}_{3}(21.5 \mu \mathrm{L}, 0.13 \mathrm{mmol})$ and 0.2 bar of HFO-1234yf for $1 \mathrm{~d}$ at room temperature yielded $Z-\left(\mathrm{CF}_{3}\right) \mathrm{CH}=\mathrm{CH}\left(\mathrm{GeEt}_{3}\right)(\mathbf{4 b}), \mathrm{CH}_{2}=\mathrm{CHCF}_{3}, \mathrm{Et}_{3} \mathrm{GeCH}_{2} \mathrm{CH}_{2}$ $\mathrm{CF}_{3}, \quad E-\left(\mathrm{CF}_{3}\right) \mathrm{CH}=\mathrm{CH}\left(\mathrm{GeEt}_{3}\right) \quad(\mathbf{1 2 b})$ and $\mathrm{CF}_{2}=\mathrm{CHCH}_{3}$ in a ratio of $1: 5: 0.6: 0.35: 0.3$. Spectroscopic data for $Z-\left(\mathrm{CF}_{3}\right) \mathrm{CH}=\mathrm{CH}\left(\mathrm{GeEt}_{3}\right)(\mathbf{4 b}):{ }^{1} \mathrm{H} \mathrm{NMR}$ $\left(300.1 \mathrm{MHz}\right.$, toluene- $\left.d_{8}\right): \delta=6.46\left(\mathrm{~d},{ }^{3} J_{\mathrm{H}-\mathrm{H}}=14.3 \mathrm{~Hz}, 1 \mathrm{H},=\mathrm{CHGeEt}_{3}\right) ; 6.29(\mathrm{dq}$, $\left.{ }^{3} J_{\mathrm{H}-\mathrm{H}}=14.3,{ }^{3} J_{\mathrm{H}-\mathrm{F}}=8.0 \mathrm{~Hz}, 1 \mathrm{H},=\mathrm{CHCF}_{3}\right) \mathrm{ppm}$. The signals for hydrogen atoms of the ethyl groups of $\mathbf{4 b}$ could not be assigned due to overlap with the signals of complexes 2 and other germylated compounds. ${ }^{19} \mathrm{~F}$ NMR $\left(282.4 \mathrm{MHz}\right.$, toluene- $\left.d_{8}\right)$ : $\delta=-62.4\left(\mathrm{~d},{ }^{3} J_{\mathrm{F}-\mathrm{H}}=8 \mathrm{~Hz}, 3 \mathrm{~F}, \mathrm{C} F_{3}\right) \mathrm{ppm}$.

Catalytic conversion of HFO-1234yf with $\mathrm{HGe}\left({ }^{n} \mathrm{Bu}\right)_{3}$. Reaction of $1(10 \mathrm{~mol} \%)$, $\left.\mathrm{HGe}^{n} \mathrm{Bu}\right)_{3}(35.0 \mu \mathrm{L}, 0.13 \mathrm{mmol})$ and 0.2 bar of HFO-1234yf for $1 \mathrm{~d}$ at room temperature yielded $Z-\left(\mathrm{CF}_{3}\right) \mathrm{CH}=\mathrm{CH}\left\{\mathrm{Ge}\left({ }^{n} \mathrm{Bu}\right)_{3}\right\} \quad(\mathbf{4 c}), \mathrm{CH}_{2}=\mathrm{CHCF}_{3},{ }^{n} \mathrm{Bu}_{3-}$ $\mathrm{GeCH}_{2} \mathrm{CH}_{2} \mathrm{CF}_{3}, E-\left(\mathrm{CF}_{3}\right) \mathrm{CH}=\mathrm{CH}\left(\mathrm{Ge}\left({ }^{n} \mathrm{Bu}\right)_{3}\right)(\mathbf{1 2 c}), \mathrm{CF}_{3} \mathrm{CH}_{2} \mathrm{CH}_{3}$ and $\mathrm{CF}_{2}=\mathrm{CHCH}_{3}$ in a ratio of $1: 3: 0.14: 0.14: 0.05: 0.33$, respectively. Spectroscopic data for $Z-\left(\mathrm{CF}_{3}\right) \mathrm{CH}=\mathrm{CH}\left\{\mathrm{Ge}\left({ }^{n} \mathrm{Bu}\right)_{3}\right\}(4 \mathrm{c}):{ }^{1} \mathrm{H}$ NMR $\left(300.1 \mathrm{MHz}\right.$, toluene- $\left.d_{8}\right): \delta=6.58(\mathrm{~d}$, $\left.{ }^{3} J_{\mathrm{H}-\mathrm{H}}=14.3 \mathrm{~Hz}, 1 \mathrm{H},=\mathrm{CHGe}\left({ }^{n} \mathrm{Bu}\right)_{3}\right) ; 6.41\left(\mathrm{dq},{ }^{3} J_{\mathrm{H}-\mathrm{H}}=14.3,{ }^{3} J_{\mathrm{H}-\mathrm{F}}=7.5 \mathrm{~Hz}, 1 \mathrm{H}\right.$, $\left.=\mathrm{CHCF}_{3}\right) \mathrm{ppm}$. The signals for hydrogen atoms of the butyl groups of $4 \mathrm{c}$ could not be assigned due to overlap with the signals of complex 2 and other 
germylated compounds. ${ }^{19} \mathrm{~F}$ NMR $\left(282.4 \mathrm{MHz}\right.$, toluene- $\left.d_{8}\right): \delta=-62.4\left(\mathrm{~d},{ }^{3} J_{\mathrm{F}-}\right.$ $\left.\mathrm{H}=7 \mathrm{~Hz}, 3 \mathrm{~F}, \mathrm{C} F_{3}\right) \mathrm{ppm}$.

Catalytic conversion of HFO-1234ze with $\mathrm{HGePh}_{3}$. Reaction of 1 (10 $\left.\mathrm{mol} \%\right)$, $\mathrm{HGePh}_{3}(40.1 \mathrm{mg}, 0.13 \mathrm{mmol})$ and $0.2 \mathrm{bar}$ of HFO-1234ze for $1 \mathrm{~d}$ at room temperature yielded $\mathrm{CH}_{2}=\mathrm{CHCF}_{3}, \mathrm{CH}_{3} \mathrm{CH}_{2} \mathrm{CF}_{3}, \mathrm{Ph}_{3} \mathrm{GeCH}_{2} \mathrm{CH}_{2} \mathrm{CF}_{3}, \mathrm{CF}_{2}=\mathrm{CHCH}_{2} \mathrm{GePh}_{3}{ }^{\text {,d }}$ and $E-\left(\mathrm{CF}_{3}\right) \mathrm{CH}=\mathrm{CH}\left(\mathrm{GePh}_{3}\right)(\mathbf{1 2 a})$ in a ratio of $0.04: 0.6: 10: 1: 0.3$, respectively. Analytical data for $E-\left(\mathrm{CF}_{3}\right) \mathrm{CH}=\mathrm{CH}\left(\mathrm{GePh}_{3}\right)(\mathbf{1 2 a}):{ }^{1} \mathrm{H}$ NMR $\left(300.1 \mathrm{MHz}\right.$, toluene- $\left.d_{8}\right): \delta=6.26$ $\left(\mathrm{dq},{ }^{3} J_{\mathrm{H}-\mathrm{H}}=18.2,{ }^{3} J_{\mathrm{H}-\mathrm{F}}=5.6 \mathrm{~Hz}, 1 \mathrm{H},=\mathrm{CHCF}_{3}\right) \mathrm{ppm}$. The signals for hydrogen atoms of the phenyl groups as well as the second olefinic proton of 12a could not be assigned due to overlap with the signals of the other germylated derivatives. ${ }^{19} \mathrm{~F}$ NMR $(282.4$ MHz, toluene- $\left.d_{8}\right): \delta=-65.9\left(\mathrm{dd},{ }^{3} J_{\mathrm{F}-\mathrm{H}}=6,{ }^{4} J_{\mathrm{F}-\mathrm{H}}=2 \mathrm{~Hz}, 3 \mathrm{~F}, \mathrm{C} F_{3}\right) \mathrm{ppm}$.

Catalytic conversion of HFO-1234ze with HGeEt $_{3}$. Reaction of 1 (10 $\left.\mathrm{mol} \%\right)$, $\mathrm{HGeEt}_{3}(21.5 \mu \mathrm{L}, 0.13 \mathrm{mmol})$ and 0.2 bar of HFO-1234ze for $2 \mathrm{~d}$ at room temperature yielded $\mathrm{CF}_{3} \mathrm{CH}=\mathrm{CH}_{2}, \mathrm{Et}_{3} \mathrm{GeCH}_{2} \mathrm{CH}_{2} \mathrm{CF}_{3}, Z-\left(\mathrm{CF}_{3}\right) \mathrm{CH}=\mathrm{CH}\left(\mathrm{GeEt}_{3}\right)$ (4b), $E-\left(\mathrm{CF}_{3}\right) \mathrm{CH}=\mathrm{CH}\left(\mathrm{GeEt}_{3}\right)$ (12b), $\mathrm{CF}_{2}=\mathrm{CHCH}_{2} \mathrm{GePh}_{3}, \mathrm{CF}_{3} \mathrm{CH}_{2} \mathrm{CH}_{3}$ and $\mathrm{CF}_{2}=\mathrm{CHCH}_{3}$ in a ratio of $11.3: 4.6: 3.2: 2.3: 1: 2.8: 1$, respectively. Analytical data for $E-\left(\mathrm{CF}_{3}\right) \mathrm{CH}=\mathrm{CH}\left(\mathrm{GeEt}_{3}\right)(\mathbf{1 2 b}):{ }^{1} \mathrm{H}$ NMR $(300.1 \mathrm{MHz}$, toluene- $\left.d_{8}\right): \delta=6.74\left(\mathrm{dq},{ }^{3} J_{\mathrm{H}-\mathrm{H}}=18.8,{ }^{4} J_{\mathrm{H}-\mathrm{F}}=2.0 \mathrm{~Hz}, 1 \mathrm{H},=\mathrm{CHGeEt}_{3}\right), 5.92$ $\left(\mathrm{dq},{ }^{3} J_{\mathrm{H}-\mathrm{H}}=18.8,{ }^{3} J_{\mathrm{H}-\mathrm{F}}=5.8 \mathrm{~Hz}, 1 \mathrm{H},=\mathrm{CHCF}_{3}\right) \mathrm{ppm}$. The signals for hydrogen atoms of the ethyl groups of $\mathbf{1 2 b}$ could not be assigned due to overlap with the signals of the other germylated derivatives. ${ }^{19} \mathrm{~F}$ NMR $\left(282.4 \mathrm{MHz}\right.$, toluene- $\left.d_{8}\right)$ : $\delta=-66.1\left(\mathrm{dd},{ }^{3} J_{\mathrm{F}-\mathrm{H}}=6,{ }^{4} J_{\mathrm{F}-\mathrm{H}}=2 \mathrm{~Hz}, 3 \mathrm{~F}, \mathrm{C} F_{3}\right) \mathrm{ppm}$.

Catalytic conversion of HFO-1234ze with $\mathrm{HGe}\left({ }^{n} \mathrm{Bu}\right)_{3}$. Reaction of $1(10 \mathrm{~mol} \%)$, $\left.\mathrm{HGe}^{n} \mathrm{Bu}\right)_{3}(35.0 \mu \mathrm{L}, 0.13 \mathrm{mmol})$ and 0.2 bar of HFO-1234ze for $1 \mathrm{~d}$ at room temperature yielded $\quad \mathrm{CF}_{3} \mathrm{CH}=\mathrm{CH}_{2}, \quad\left({ }^{n} \mathrm{Bu}\right)_{3} \mathrm{GeCH}_{2} \mathrm{CH}_{2} \mathrm{CF}_{3}, \quad Z-\left(\mathrm{CF}_{3}\right) \mathrm{CH}=$ $\mathrm{CH}\left(\mathrm{Ge}\left({ }^{n} \mathrm{Bu}\right)_{3}\right)(\mathbf{4 c}), E-\left(\mathrm{CF}_{3}\right) \mathrm{CH}=\mathrm{CH}\left(\mathrm{Ge}\left({ }^{n} \mathrm{Bu}\right)_{3}\right)(\mathbf{1 2 c}), \mathrm{CF}_{2}=\mathrm{CHCH}_{2} \mathrm{GePh}_{3}, \mathrm{CF}_{3-}$ $\mathrm{CH}_{2} \mathrm{CH}_{3}$ and $\mathrm{CF}_{2}=\mathrm{CHCH}_{3}$ in a ratio of $14: 4.4: 2.1: 3.7: 1: 4: 1$, respectively. Analytical data for $E-\left(\mathrm{CF}_{3}\right) \mathrm{CH}=\mathrm{CH}\left(\mathrm{Ge}\left({ }^{n} \mathrm{Bu}\right)_{3}\right)(\mathbf{1 2 c}):{ }^{1} \mathrm{H}$ NMR $(300.1 \mathrm{MHz}$, toluene- $\left.d_{8}\right): \delta=6.95\left(\mathrm{dq},{ }^{3} J_{\mathrm{H}-\mathrm{H}}=18.9,{ }^{4} J_{\mathrm{H}-\mathrm{F}}=2.0 \mathrm{~Hz}, 1 \mathrm{H},=\mathrm{CHGe}\left({ }^{n} \mathrm{Bu}\right)_{3}\right), 6.08$ $\left(\mathrm{dq},{ }^{3} \mathrm{~J}_{\mathrm{H}-\mathrm{H}}=18.9,{ }^{3} J_{\mathrm{H}-\mathrm{F}}=5.7 \mathrm{~Hz}, 1 \mathrm{H},=\mathrm{CHCF}_{3}\right) \mathrm{ppm}$. The signals for hydrogen atoms of the butyl groups of $12 \mathrm{c}$ could not be assigned due to overlap with the signals of the other germylated derivatives. ${ }^{19} \mathrm{~F} \mathrm{NMR}\left(282.4 \mathrm{MHz}\right.$, toluene- $\left.d_{8}\right): \delta=$ $-66.0\left(\mathrm{dd},{ }^{3} \mathrm{~J}_{\mathrm{F}-\mathrm{H}}=6,{ }^{4} J_{\mathrm{F}-\mathrm{H}}=2 \mathrm{~Hz}, 3 \mathrm{~F}, \mathrm{C} F_{3}\right) \mathrm{ppm} .{ }^{13} \mathrm{C}\left\{{ }^{1} \mathrm{H}\right\} \mathrm{NMR}(75.5 \mathrm{MHz}$, toluene$\left.d_{8}\right): \delta=144.8\left(\mathrm{~m}\right.$, observed by ${ }^{1} \mathrm{H}^{-13}{ }^{13} \mathrm{C}$ HMQC NMR experiment, $\left.=C \mathrm{HGe}\left({ }^{n} \mathrm{Bu}\right)_{3}\right)$; 130.6 (m, observed by ${ }^{1} \mathrm{H}^{13}{ }^{13} \mathrm{C}$ HMQC NMR experiment, $\left.=\mathrm{CH}\left(\mathrm{CF}_{3}\right)\right) \mathrm{ppm}$.

\section{General procedure for the catalytic conversion of fluorinated olefins with $\left[\mathrm{Rh}\left(\mathrm{Si}(\mathrm{OEt})_{3}\right)\left(\mathrm{PEt}_{3}\right)_{3}\right](5)$ or $\left[\mathrm{Rh}(\mathrm{H})\left(\mathrm{PEt}_{3}\right)_{3}\right](8)$ and $\mathrm{HSi}(\mathrm{OEt})_{3}$}

In a Young $\mathrm{NMR}$ tube $\left[\mathrm{Rh}\left(\mathrm{Si}(\mathrm{OEt})_{3}\right)\left(\mathrm{PEt}_{3}\right)_{3}\right](5)(8.0 \mathrm{mg}, 0.013 \mathrm{mmol})$ or $\left[\mathrm{Rh}(\mathrm{H})\left(\mathrm{PEt}_{3}\right)_{3}\right](8)(6.0 \mathrm{mg}, 0.013 \mathrm{mmol})$ was dissolved in $\mathrm{C}_{6} \mathrm{D}_{6}(0.4 \mathrm{~mL})$ and $\mathrm{HSi}(\mathrm{OEt})_{3}(25 \mu \mathrm{L}, 0.13 \mathrm{mmol})$ was added to the solution. The solution was cooled to $77 \mathrm{~K}$, degassed in vacuo, and pressurized with HFO-1234yf or HFO-1234ze to 0.2 bar. After warming up to room temperature the reaction was monitored using NMR spectroscopy. After the reaction time at room temperature the ${ }^{1} \mathrm{H}$ and ${ }^{19} \mathrm{~F}$ NMR spectroscopic data revealed the complete conversion of $\mathrm{HSi}(\mathrm{OEt})_{3}$, and the formation of the $\mathrm{FSi}(\mathrm{OEt})_{3}$ as well as the products.

Catalytic conversion of HFO-1234yf with $\left[\mathrm{Rh}\left(\mathrm{Si}(\mathrm{OEt})_{3}\right)\left(\mathrm{PEt}_{3}\right)_{3}\right](5)$. Reaction of 5 $(10 \mathrm{~mol} \%), \mathrm{HSi}(\mathrm{OEt})_{3}(0.13 \mathrm{mmol})$ and $0.2 \mathrm{bar}$ of HFO-1234yf for $8 \mathrm{~h}$ at room 
temperature yielded $Z-\left(\mathrm{CF}_{3}\right) \mathrm{CH}=\mathrm{CH}\left(\mathrm{Si}(\mathrm{OEt})_{3}\right)(7),(\mathrm{OEt})_{3} \mathrm{SiCH}_{2} \mathrm{CH}_{2} \mathrm{CF}_{3}$ (ref. 39), $\mathrm{CH}_{2}=\mathrm{CHCF}_{3}$, and $\mathrm{CH}_{3} \mathrm{CH}_{2} \mathrm{CF}_{3}$ in a ratio of $1: 1.5: 16.7: 4.6$, respectively.

Catalytic conversion of HFO-1234ze with $\left[\mathrm{Rh}\left(\mathrm{Si}(\mathrm{OEt})_{3}\right)\left(\mathrm{PEt}_{3}\right)_{3}\right](5)$. Reaction of $5(10 \mathrm{~mol} \%), \mathrm{HSi}(\mathrm{OEt})_{3}(0.13 \mathrm{mmol})$ and $0.2 \mathrm{bar}$ of HFO-1234ze for $8 \mathrm{~h}$ at room temperature yielded $\mathrm{CH}_{2}=\mathrm{CHCF}_{3}, \mathrm{CH}_{3} \mathrm{CH}_{2} \mathrm{CF}_{3},(\mathrm{OEt})_{3} \mathrm{SiCH}_{2} \mathrm{CH}_{2} \mathrm{CF}_{3}$ (ref. 39) and an unknown $\mathrm{CF}_{3} \mathrm{CH}_{2}$ containing compound in a ratio of $15: 8.4: 1: 4.1$, respectively.

Catalytic conversion of HFO-1234yf with $\left[\mathrm{Rh}(\mathrm{H})\left(\mathrm{PEt}_{3}\right)_{3}\right]$ (8). Reaction of 8 (10 mol\%), $\mathrm{HSi}(\mathrm{OEt})_{3}(0.13 \mathrm{mmol})$ and 0.2 bar of HFO-1234yf for $2 \mathrm{~h}$ at room temperature yielded $\mathrm{CH}_{2}=\mathrm{CHCF}_{3}, \mathrm{CH}_{3} \mathrm{CH}_{2} \mathrm{CF}_{3}$ and $(\mathrm{OEt})_{3} \mathrm{SiCH}_{2} \mathrm{CH}_{2} \mathrm{CF}_{3}$ (ref. 39) in a ratio of $16.8: 9: 1$, respectively.

Catalytic conversion of $\mathrm{HFO}-1234 z e$ with $\left[\mathrm{Rh}(\mathrm{H})\left(\mathrm{PEt}_{3}\right)_{3}\right](8)$. Reaction of 8 $(10 \mathrm{~mol} \%), \mathrm{HSi}(\mathrm{OEt})_{3}(0.13 \mathrm{mmol})$ and $0.2 \mathrm{bar}$ of HFO-1234ze for $40^{\prime}$ at room temperature yielded $\mathrm{CH}_{2}=\mathrm{CHCF}_{3}, \mathrm{CH}_{3} \mathrm{CH}_{2} \mathrm{CF}_{3}$ and $(\mathrm{OEt})_{3} \mathrm{SiCH}_{2} \mathrm{CH}_{2} \mathrm{CF}_{3}$ (ref. 39) in a ratio of $9.5: 5.5: 1$, respectively.

\section{Conflicts of interest}

There are no conflicts to declare.

\section{Acknowledgements}

We would like to acknowledge the AvH Foundation and the CRC 1349 "FluorineSpecific Interactions" funded by the Deutsche Forschungsgemeinschaft (DFG, German Research Foundation, project 387284271) for financial support. We also thank Dr Mike Ahrens for his support with DFT calculations.

\section{Notes and references}

1 (a) Y. Zhou, J. Wang, Z. Gu, S. Wang, W. Zhu, J. L. Aceña, V. A. Soloshonok, K. Izawa and H. Liu, Chem. Rev., 2016, 116, 422-518; (b) P. Kirsch, Modern Fluoroorganic Chemistry: Synthesis, Reactivity and Applications, Wiley-VCH, Weinheim, 2nd edn, 2013; (c) P. Jeschke, Pest Manage. Sci., 2010, 66, 10-27; (d) E. P. Gillis, K. J. Eastman, M. D. Hill, D. J. Donnelly and N. A. Meanwell, J. Med. Chem., 2015, 58, 8315-8359; (e) S. Purser, P. R. Moore, S. Swallow and V. Gouverneur, Chem. Soc. Rev., 2008, 37, 320-330.

2 (a) P. Javidmand and K. A. Hoffmann, Int. J. Refrig., 2016, 69, 114-135; (b) G. Righetti, C. Zilio and G. A. Longo, Int. J. Refrig., 2015, 54, 1-9.

3 (a) M. R. Crimmin, C. Bakewell and A. White, Angew. Chem., Int. Ed., 2018, 57, 6638-6642; (b) H. Sakaguchi, M. Ohashi and S. Ogoshi, Angew. Chem., Int. Ed., 2018, 57, 328-332; (c) T. Braun, G. Meißner, E. Kemnitz and K. Kretschmar, Angew. Chem., Int. Ed., 2017, 56, 16338-16341; (d) H. Sakaguchi, Y. Uetake, M. Ohashi, T. Niwa, S. Ogoshi and T. Hosoya, J. Am. Chem. Soc., 2017, 139, 12855-12862; (e) Y. Li, D.-H. Tu, Y.-J. Gu, B. Wang, Y.-Y. Wang, Z.-T. Liu, Z.-W. Liu and J. Lu, Eur. J. Org. Chem., 2015, 2015, 4340-4343; (f) Y. Hiraoka, T. Kawasaki-Takasuka, Y. Morizawa and T. Yamazaki, J. Fluorine Chem., 2015, 179, 71-76; $(g)$ Y. L. Yagupolskii, N. V. Pavlenko, S. V. Shelyazhenko, A. A. Filatov, M. M. Kremlev, A. I. Mushta, I. I. Gerus, S. Peng, V. A. Petrov and M. Nappa, J. Fluorine Chem., 2015, 179, 134-141. 
4 M. Talavera, C. N. Von Hahmann, R. Müller, M. Kaupp and T. Braun, Angew. Chem., Int. Ed., 2019, 58, 10688-10692.

5 (a) N. A. LaBerge and J. A. Love, in Organometallic Fluorine Chemistry, ed. T. Braun and R. Hughes, Springer, Cham, 2015, vol. 52; (b) M. E. Slaney, M. J. Ferguson, R. McDonald and M. Cowie, Organometallics, 2012, 31, 13841396; (c) N. O. Andrella, K. Liu, B. Gabidullin, M. Vasiliu, D. A. Dixon and R. T. Baker, Organometallics, 2018, 37, 422-432; (d) R. Kojima, S. Akiyama and H. Ito, Angew. Chem., Int. Ed., 2018, 57, 7196-7199; (e) T. Fujita, R. Morioka, T. Arita and J. Ichikawa, Chem. Commun., 2018, 54, 1293812941; $(f)$ L. M. Milner, L. M. Hall, N. E. Pridmore, M. K. Skeats, A. C. Whitwood, J. M. Lynam and J. M. Slattery, Dalton Trans., 2016, 45, 1717-1726; $(g)$ O. Eisenstein, J. Milani and R. N. Perutz, Chem. Rev., 2017, 117, 8710-8753; (h) T. Ahrens, J. Kohlmann, M. Ahrens and T. Braun, Chem. Rev., 2015, 115, 931-972; (i) J.-D. Hamel and J.-F. Paquin, Chem. Commun., 2018, 54, 10224-10239; (j) T. Fujita, K. Fuchibe and J. Ichikawa, Angew. Chem., Int. Ed., 2019, 58, 390-402; (k) T. Braun and R. N. Perutz, Chem. Commun., 2002, 2749-2757; (l) S. A. Macgregor, Chem. Soc. Rev., 2007, 36, 67-76; $(m)$ H. Amii and K. Uneyama, Chem. Rev., 2009, 109, 2119-2183; $(n)$ A. D. Sun and J. A. Love, Dalton Trans., 2010, 39, 10362-10374; (o) J.-F. Paquin, Synlett, 2011, 2011, 289-293; (p) M. F. Kuehnel, D. Lentz and T. Braun, Angew. Chem., Int. Ed., 2013, 52, 3328-3348; (q) P. A. Champagne, Y. Benhassine, J. Desroches and J.-F. Paquin, Angew. Chem., Int. Ed., 2014, 53, 13835-13839; (r) W. Chen, C. Bakewell and M. R. Crimmin, Synthesis, 2017, 49, 810-821; $(s)$ E. Clot, O. Eisenstein, N. Jasim, S. A. Macgregor, J. E. McGrady and R. N. Perutz, Acc. Chem. Res., 2011, 44, 333-348; $(t)$ S. A. Johnson, J. A. Hatnean and M. E. Doster, in Prog. Inorg. Chem., Wiley, 2011, vol. 57, pp. 255-352; (u) J. Weaver and S. Senaweera, Tetrahedron, 2014, 70, 7413-7428; (v) U. Mazurek and H. Schwarz, Chem. Commun., 2003, 1321-1326; $(w)$ W. D. Jones, Dalton Trans., 2003, 3991-3995, DOI: 10.1039/ b307232k; (x) R. P. Hughes, Eur. J. Inorg. Chem., 2009, 2009, 4591-4606; $(y)$ H. Torrens, Coord. Chem. Rev., 2005, 249, 1957-1985.

6 (a) G. Meier and T. Braun, Angew. Chem., Int. Ed., 2009, 48, 1546-1548; (b) R. J. Lindup, T. B. Marder, R. N. Perutz and A. C. Whitwood, Chem. Commun., 2007, 3664-3666; (c) T. Stahl, H. F. T. Klare and M. Oestreich, ACS Catal., 2013, 3, 1578-1587; (d) Y. R. Luo, Comprehensive Handbook of Chemical Bond Energies, CRC Press, Boca Raton, FL, 2007; (e) N. A. Phillips, A. J. P. White and M. R. Crimmin, Adv. Synth. Catal., 2019, 361, 3351-3358.

7 (a) T. Braun, D. Noveski, B. Neumann and H.-G. Stammler, Angew. Chem., Int. Ed., 2002, 41, 2745-2748; (b) T. Braun, F. Wehmeier and K. Altenhöner, Angew. Chem., Int. Ed., 2007, 46, 5321-5324; (c) D. Noveski, T. Braun, M. Schulte, B. Neumann and H.-G. Stammler, Dalton Trans., 2003, 4075-4083; (d) T. Ahrens, M. Teltewskoi, M. Ahrens, T. Braun and R. Laubenstein, Dalton Trans., 2016, 45, 17495-17507; (e) T. Braun, D. Noveski, M. Ahijado and F. Wehmeier, Dalton Trans., 2007, 3820-3825.

8 T. Ahrens, M. Ahrens, T. Braun, B. Braun and R. Herrmann, Dalton Trans., 2016, 45, 4716-4728.

9 A. L. Raza, J. A. Panetier, M. Teltewskoi, S. A. Macgregor and T. Braun, Organometallics, 2013, 32, 3795-3807. 
10 A. L. Raza, M. F. Kuehnel, M. Talavera, M. Teltewskoi, M. Ahrens, P. Kläring, T. Braun and D. Lentz, J. Fluorine Chem., 2018, 214, 80-85.

11 D. Noveski, T. Braun and S. Krückemeier, J. Fluorine Chem., 2004, 125, 959966.

12 R. N. Haszeldine, C. R. Pool and A. E. Tipping, J. Chem. Soc., Perkin Trans. 1, 1974, 2293-2296.

13 R. Lide, Handbook of Chemistry and Physics, CRC Press, New York, 76th edn, 1995.

14 A. K. Brisdon, I. R. Crossley, R. G. Pritchard and J. E. Warren, Inorg. Chem., 2002, 41, 4748-4755.

15 A. K. Brisdon, I. R. Crossley, J. A. Greenall, R. G. Pritchard and J. E. Warren, J. Fluorine Chem., 2004, 125, 1099-1103.

16 A. K. Brisdon, R. G. Pritchard and A. Thomas, Organometallics, 2012, 31, 13411348.

17 (a) M. Mantina, A. C. Chamberlin, R. Valero, C. J. Cramer and D. G. Truhlar, J. Phys. Chem. A, 2009, 113, 5806-5812; (b) R. Chauvin, J. Phys. Chem., 1992, 96, 9194-9197.

18 (a) L. Zámostná and T. Braun, Angew. Chem., Int. Ed., 2015, 54, 10652-10656; (b) J. J. Gambaro, W. H. Hohman and D. W. Meek, Inorg. Chem., 1989, 28, 4154-4159.

19 (a) M. F. Kuehnel, P. Holstein, M. Kliche, J. Krüger, S. Matthies, D. Nitsch, J. Schutt, M. Sparenberg and D. Lentz, Chem.-Eur. J., 2012, 18, 10701-10714; (b) B. M. Kraft and W. D. Jones, J. Am. Chem. Soc., 2002, 124, 8681-8689; (c) C. J. Bourgeois, R. P. Hughes, J. Yuan, A. G. DiPasquale and A. L. Rheingold, Organometallics, 2006, 25, 2908-2910; (d) R. T. Thornbury and F. D. Toste, Angew. Chem., Int. Ed., 2016, 55, 11629-11632.

20 (a) D. Noveski, T. Braun, B. Neumann, A. Stammler and H.-G. Stammler, Dalton Trans., 2004, 4106-4119; (b) S. I. Kalläne, M. Teltewskoi, T. Braun and B. Braun, Organometallics, 2015, 34, 1156-1169.

21 A. Foris, Magn. Reson. Chem., 2004, 42, 534-555.

22 M. Teltewskoi, J. A. Panetier, S. A. Macgregor and T. Braun, Angew. Chem., Int. Ed., 2010, 49, 3947-3951.

23 A. K. Brisdon, I. R. Crossley, R. G. Pritchard, G. Sadiq and J. E. Warren, Organometallics, 2003, 22, 5534-5542.

24 D. D. Perrin and W. L. F. Armarego, Purification of Laboratory Chemicals, Butterworth/Heinemann, London/Oxford, 3rd edn, 1988.

25 G. M. Sheldrick, SHELXT-2014, Program for the Solution of Crystal Structures from X-Ray Data, University of Göttingen, Germany, 2013.

26 G. M. Sheldrick, SHELXL-2013, Program for the Refinement of Crystal Structures from X-Ray Data, University of Göttingen, Germany, 2013.

27 G. M. Sheldrick, SADABS, Program for Empirical Absorption Correction of Area Detector Data, University of Göttingen, Germany, 1996.

28 (a) R. Ahlrichs, M. Bär, M. Häser, H. Horn and C. Kölmel, Chem. Phys. Lett., 1989, 162, 165-169; (b) O. Treutler and R. Ahlrichs, J. Chem. Phys., 1995, 102, 346-354; (c) M. Von Arnim and R. Ahlrichs, J. Comput. Chem., 1998, 19, 1746-1757; (d) P. Deglmann, K. May, F. Furche and R. Ahlrichs, Chem. Phys. Lett., 2004, 384, 103-107.

29 (a) A. D. Becke, Phys. Rev. A: At., Mol., Opt. Phys., 1988, 38, 3098-3100; (b) J. P. Perdew, Phys. Rev. B: Condens. Matter Mater. Phys., 1986, 33, 8822-8824. 
30 A. Schäfer, H. Horn and R. Ahlrichs, J. Chem. Phys., 1992, 97, 2571-2577.

31 (a) K. Eichkorn, F. Weigend, O. Treutler and R. Ahlrichs, Theor. Chem. Acc., 1997, 97, 119-124; (b) D. Andrae, U. Häußermann, M. Dolg, H. Stoll and H. Preuß, Theor. Chim. Acta, 1990, 77, 123-141.

32 (a) K. Eichkorn, O. Treutler, H. Öhm, M. Häser and R. Ahlrichs, Chem. Phys. Lett., 1995, 242, 652-660; (b) F. Weigend, Phys. Chem. Chem. Phys., 2006, 8, 1057-1065; (c) M. Sierka, A. Hogekamp and R. Ahlrichs, J. Chem. Phys., 2003, 118, 9136-9148.

33 (a) S. Grimme, J. Antony, S. Ehrlich and H. Krieg, J. Chem. Phys., 2010, 132, 154104; (b) S. Grimme, S. Ehrlich and L. Goerigk, J. Comput. Chem., 2011, 32, 1456-1465.

34 (a) A. Klamt and G. Schüürmann, J. Chem. Soc., Perkin Trans. 2, 1993, 799-805; (b) A. Klamt, J. Phys. Chem., 1995, 99, 2224-2235.

35 G. W. T. M. J. Frisch, H. B. Schlegel, G. E. Scuseria, M. A. Robb, J. R. Cheeseman, G. Scalmani, V. Barone, G. A. Petersson, H. Nakatsuji, X. Li, M. Caricato, A. Marenich, J. Bloino, B. G. Janesko, R. Gomperts, B. Mennucci, H. P. Hratchian, J. V. Ortiz, A. F. Izmaylov, J. L. Sonnenberg, D. Williams-Young, F. Ding, F. Lipparini, F. Egidi, J. Goings, B. Peng, A. Petrone, T. Henderson, D. Ranasinghe, V. G. Zakrzewski, J. Gao, N. Rega, G. Zheng, W. Liang, M. Hada, M. Ehara, K. Toyota, R. Fukuda, J. Hasegawa, M. Ishida, T. Nakajima, Y. Honda, O. Kitao, H. Nakai, T. Vreven, K. Throssell, J. A. Montgomery Jr, J. E. Peralta, F. Ogliaro, M. Bearpark, J. J. Heyd, E. Brothers, K. N. Kudin, V. N. Staroverov, T. Keith, R. Kobayashi, J. Normand, K. Raghavachari, A. Rendell, J. C. Burant, S. S. Iyengar, J. Tomasi, M. Cossi, J. M. Millam, M. Klene, C. Adamo, R. Cammi, J. W. Ochterski, R. L. Martin, K. Morokuma, O. Farkas, J. B. Foresman, and D. J. Fox, Gaussian 09, Revision D.01, Gaussian, Inc., Wallingford CT, 2016.

36 K. A. Peterson, D. Figgen, M. Dolg and H. Stoll, J. Chem. Phys., 2007, 126, 124101.

37 (a) T. H. Dunning Jr, J. Chem. Phys., 1989, 90, 1007-1023; (b) D. E. Woon and T. H. Dunning Jr, J. Chem. Phys., 1993, 98, 1358-1371.

38 P. H. M. Budzelaar, gNMR, Version 4.1, Adept Scientific plc, Letchworth, 2001. 39 I. Ojima, T. Fuchikami and M. Yatabe, J. Organomet. Chem., 1984, 260, 335346. 